\title{
A formação do Grupo Votorantim: as origens de um grupo econômico brasileiro no setor têxtil de São Paulo (1891-1929)*
}

\author{
Gustavo Pereira da Silva ** \\ Armando João Dalla Costa ${ }^{* * *}$
}

\begin{abstract}
Resumo
As origens dos maiores grupos econômicos brasileiros permanecem como lacunas na historiografia econômica. A Votorantim, oitavo maior grupo brasileiro em 2007, teve origem em 1891, quando o banco União de São Paulo criou na cidade de Sorocaba (SP) a Fábrica Têxtil Votorantim. Analisando fontes primárias (escritura, balanços patrimoniais, demonstrações de lucros e perdas, relatórios de diretoria), vemos que a Fábrica Votorantim estava entre as maiores têxteis algodoeiras paulistas em 1918, quando o Banco União faliu e seu espólio foi adquirido por Antonio Pereira Ignácio. Em 1919, Pereira Ignácio formaria o Grupo Votorantim (Sociedade Anônima Fábrica Votorantim), com atuação no setor têxtil, exploração de cal, cimento, imobiliário, além da ferrovia particular. As empresas do Grupo, após uma modernização no início dos anos 1920, aumentariam sua produtividade, destacandose a Fábrica Votorantim, que se tornou a maior firma têxtil algodoeira de São Paulo em 1925.
\end{abstract}

Palavras-chave: Votorantim; Banco União; Pereira Ignácio, 1875-1951; Têxtil; Grupo econômico.

\section{Abstract \\ The formation of the Votorantim Group: the origins of a Brazilian business group in São Paulo's textile sector (1891-1924)}

The origins of the largest Brazilian business groups are still seen as gaps in economic historiography. Votorantim, Brazil's eighth largest group in 2007, was created in 1891, when the Union Bank of São Paulo created the Votorantim Textile Factory in the city of Sorocaba (SP). Analyzing primary sources (scripture, balance sheets, profit and loss statements, management reports), we see that the Votorantim Factory was among São Paulo's largest cotton textile companies in 1918, when the Union Bank went bankrupt and its assets were purchased by Antonio Pereira Ignacio. In 1919, Pereira Ignacio formed the Votorantim Group (S. A. Votorantim Factory), acting in the textile sector, lime exploration, cement, real estate, as well as private railway. The group's companies, after modernization in the early 1920s, increased productivity, in particular the Votorantim factory, which became the largest cotton textile firm in São Paulo in 1925.

Keywords: Votorantim; Bank União; Pereira Ignacio; Textile; Business group. JEL L67, N66, N86.

* Artigo recebido em 24 de dezembro de 2015 e aprovado em 9 de abril de 2017. A pesquisa é resultado do projeto S.A. Indústrias Votorantim (1925-1980): formação e expansão de um grupo econômico no desenvolvimento industrial do Brasil pertencente à Chamada MCTI/CNPq/MEC/Capes n. 43/2013. Agradecemos ao Centro de Memória do Grupo Votorantim, situado na cidade de São Paulo, pelo acesso aos documentos utilizados no trabalho.

** Professor no Departamento de Economia e no Programa de Pós-Graduação em Economia da Universidade Federal de São Carlos (Ufscar). São Carlos, SP, Brasil. E-mail: gustavopsilva@ufscar.br.

*** Professor no Departamento de Economia e no Programa de Pós-Graduação em Desenvolvimento Econômico da Universidade Federal do Paraná (UFPR), Curitiba, PR, Brasil. E-mail: ajdcosta@uol.br. 


\section{Introdução}

O crescimento industrial brasileiro durante a Primeira República (18891930), processo que, no caso do estado de São Paulo, foi induzido pela rentabilidade e oportunidades geradas pelo café, teve o predomínio de uma indústria de bens de consumo assalariado, com destaque para o setor têxtil (Mello, 2009; Cano, 1981; Aureliano, 1999; Silva, 1995) ${ }^{1}$. Em 1907, este setor representava 24,6\% do valor da produção industrial brasileira, secundado pelos alimentos processados com 19,1\%, sendo que o estado do Rio de Janeiro abrigava $38 \%$ da produção manufatureira nacional, enquanto São Paulo tinha 16\% (Franco; Lago, 2012, p. 201).

Naquele momento, a indústria têxtil brasileira era a de maior capacidade instalada na América Latina, visto que em 1910, havia 137 fábricas que contavam com 35 mil teares, 1 milhão de fusos e 55 mil operários, ao passo que, as 145 fábricas têxteis mexicanas tinham 24.436 teares, 730.297 fusos e 32.147 trabalhadores - na Argentina havia 1.200 teares e 9 mil fusos no ano de 1911 (Stein, 1979, p. 191; King, 2003, p. 256-258; Rock, 2008, p. 547; Bertola; Ocampo, 2012, p. 128-129)².

Nos anos 1920, ocorreria uma mudança geográfica na concentração industrial brasileira, com a ascensão das fábricas do estado de São Paulo, de onde vinham agora $31,5 \%$ do valor da produção industrial brasileira, secundadas pelas fábricas do Rio de Janeiro com 28,2\% do total (Cano, 1981, p. 296) ${ }^{3}$. Dos ramos que compunham o setor têxtil paulista - fiação e tecelagem de algodão, fiação e tecelagem de juta, fábricas de seda natural e artificial (rayon), as malharias e as fábricas de $l \tilde{a}$ - o ramo algodoeiro era o principal, pois, no ano de 1928, enquanto suas fábricas representavam $31,5 \%$ das unidades do setor, ao mesmo tempo, nelas estavam $64,5 \%$ do capital, $60,6 \%$ dos trabalhadores e $74,6 \%$ da força motriz,

(1) É importante destacar que a relação café-indústria não é única via explicativa para a formação industrial brasileira. No caso do estado do Rio de Janeiro, sobretudo da Capital Federal, que era o principal centro industrial do Brasil até a década de 1910, a expansão das fábricas em setores como o têxtil, deu-se de maneira acentuada nas décadas de 1880 e 1890, justamente quando ocorreria a crise na lavoura exportadora de café fluminense. Neste sentido, a evolução industrial carioca aponta para a formação do capital comercial durante o século XIX e sua união com os bancos para formação de empresas, como no caso de grandes atacadistas de tecidos que se tornaram industriais, sem olvidar o papel fundamental da cidade do Rio de Janeiro como grande centro irradiador do comércio nacional através de seu porto (Levy, 1994; Lamarão, 2012; Ferreira; Gomes, 1988; Melo, 2002).

(2) Haber (1991, p. 561) demonstra que a liderança brasileira na indústria têxtil algodoeira latino-americana se deu a partir das mudanças institucionais no início da década de 1890, quando foi facilitada a formação de empresas e seu acesso ao mercado de capitais, ao passo que, no México, o governo de Porfírio Diaz limitava a abertura do mercado de capitais, medida que teria restringido o avanço das têxteis mexicanas.

(3) Algumas causas para a regressão da indústria do Rio de Janeiro frente à ascensão das fábricas de São Paulo podem ser elencadas em meio à I Guerra Mundial (1914-1918): o aumento nas tarifas de exportação do algodão efetuado pelos outros Estados brasileiros, o aumento no custo dos transportes ferroviários e da energia elétrica (cobrança das tarifas em ouro pela Light), o fato da expansão industrial de São Paulo ter permitido a diminuição de suas compras de bens industriais de outros Estados, uma taxa média salarial no Rio de Janeiro, então a capital federal, maior que em outros Estados (Lamarão, 2012, p. 17; Levy, 1994, p. 206-207; Gomes; Ferreira, 1988, p. 19; Cano, 2002, p. 52; Cano, 1981, p. 244-249). 
elementos que reunidos permitiam ao ramo algodoeiro alcançar $43,4 \%$ da produção do setor (Negri, 1996, p. 37; Loureiro, 2006, p. 34).

$\mathrm{O}$ setor têxtil paulista caracterizava-se nas décadas iniciais do século $\mathrm{XX}$ pela existência de grandes empresas, algumas delas com investimentos diversificados e que competiam em um mercado em expansão (Aureliano, 1999, p. 31-33 $)^{4}$. Uma das maiores empresas paulistas de tecidos de algodão na década de 1920 era a Fábrica Votorantim, localizada na cidade de Sorocaba. Criada pelo banco União de São Paulo em 1891, a fábrica têxtil era parte de um complexo industrial composto também pela Estrada de Ferro Votorantim, ferrovia particular que interligava as instalações têxteis - que gerariam o município de Votorantim (SP) aos trilhos da E. F. Sorocabana, e por uma pequena central hidrelétrica que se valia das terras compradas às margens do rio Sorocaba para o fornecimento de energia aos fusos e teares.

Vários trabalhos abordaram a indústria têxtil de São Paulo, porém, estas análises, na maioria das vezes, não tiveram como foco uma única empresa $^{5}$. Especificamente sobre a Votorantim, os trabalhos existentes ${ }^{6}$ exibem um $^{-}$ duplo viés: de um lado, Caldeira (2007) tenta descrever a evolução do Grupo, mas sem contextualizar com o todo da indústria paulista, o que limita as conclusões sobre o peso da Votorantim no setor têxtil de São Paulo. De outra parte, Santos (2008) desenvolve sua análise com uma preocupação maior acerca do processo de internacionalização do Grupo, que foi impulsionado na década de 1980. Dessa forma, permanecem lacunas sobre a formação do Grupo Votorantim, o que se deu no final do século XIX e décadas iniciais do XX. Ademais, há uma escassez de informações sobre a origem dos maiores grupos econômicos nacionais ${ }^{7}$, lista em

(4) Em 1925, no setor têxtil algodoeiro paulista foram listadas 64 fábricas, sendo que nas 10 maiores empresas - pelo volume do capital investido - estavam $48 \%$ do capital empregado neste ramo têxtil, $44 \%$ dos operários, 38\% dos teares e 49\% dos fusos (Boletim, abr. 1926, p. 63-67). Esta concentração em grandes empresas se devia à: necessidade de escalas mínimas de produção, a compensar lacunas logísticas - como a precária integração do mercado nacional - que demandavam a utilização de vários fusos e teares, implicando na aquisição de muitas máquinas e, principalmente, investimentos na geração de energia para alimentar a produção.

(5) Baer (1975); Carone (2001); Cano (1981); Stein (1979); Loureiro (2006); Negri (1996); Suzigan (2000); Dean (1971); Versiani e Versiani (1977); Versiani (1984); Ribeiro (1988) e Albuquerque (1982).

(6) Alguns trabalhos se reportaram às figuras-chaves para o desenvolvimento do Grupo Votorantim, como Scantimburgo (1975) e Pastore (2013) e Marcovitch (2009).

(7) Os grupos econômicos, conceituação teórica utilizada na descrição das grandes empresas de países emergentes (China, América Latina, Coréia, Turquia) - surgidas principalmente no início do século XX - são descritos como uniões de firmas que podem ser juridicamente independentes, mas que atuam de maneira conjunta através de laços formais - como o patrimônio - e/ou informais, como família. Estas associações de empresas visavam diminuir custos de transação (transporte, acesso ao crédito) em economias nacionais ainda em formação. No caso do Brasil, geralmente os maiores grupos econômicos, muitos surgidos na primeira metade do século XX, tratam-se de grupos que atuam em, ao menos, três setores econômicos diferentes, como se dará no caso do Grupo Votorantim na década de 1920 (Granovetter, 2005, p. 429; Khanna e Yafhe, 2007, p. 331; Colpan e Hikino, 2010, p. 17; Gonçalves; 1991, p. 181; Aldrighi e Postali, 2010, p. 371; Valdaliso, 2002, p. 582; Leff, 1974, p. 89). 
que o Grupo Votorantim situava-se como o maior conglomerado industrial de origem privada/familiar no ano de 2007 (Aldrighi e Postali, 2010, p. 355-356) ${ }^{8}$.

Posto isso, o artigo tem como objetivo analisar a formação do Grupo Votorantim entre 1891 a 1929, tendo como foco a atuação da Fábrica Votorantim no setor têxtil algodoeiro do estado de São Paulo. O recorte histórico busca abarcar como se deu a formação da firma têxtil sorocabana no início da década de 1890, e se estende até o final da década de 1920, quando a Votorantim já era uma das principais empresas têxteis do estado de São Paulo. Sendo assim, podemos ver o comportamento de uma das maiores firmas têxteis brasileiras em meio ao cenário de crise no setor durante a segunda metade dos anos 1920, período em que aumentaram as importações de tecidos, o que deprimiu a lucratividade de grandes empresas do setor, como a Votorantim (Stein, 1979, p. 135; Haber, 1992, p. 343) 9 .

Para tanto, utilizamos a escritura de formação da Sociedade Anônima Fábrica Votorantim em janeiro de 1918, bem como suas demonstrações contábeis (Balanços Gerais e Demonstrações de Lucros e Perdas) e os Relatórios de Diretoria, recobrindo o período 1891-1929. Ademais, a análise está apoiada nos levantamentos sobre a indústria paulista no início do século XX (Boletim da Diretoria de Indústria e Comércio do Estado de São Paulo).

Na seção 1, o trabalho retrata o banco União de São Paulo e como ele criou a Fábrica Têxtil Votorantim em Sorocaba-SP no ano de 1891. Na seção 2, analisamos a participação da Fábrica Votorantim no setor têxtil paulista até a I Guerra Mundial, quando ela já era uma das maiores empresas do ramo têxtil algodoeiro. Na seção 3, abordamos a falência do banco União em janeiro de 1918, quando seus bens foram arrematados em leilão por Antonio Pereira Ignácio e Nicolau Scarpa para a formação da Sociedade Anônima Fábrica Votorantim (SAFV). Na seção 4, ressaltamos como os diversos empreendimentos arrematados por Pereira Ignácio e Scarpa - fábrica têxtil (Fábrica Votorantim) e de investimentos paralelos (Caieiras de Itupararanga, Estrada de Ferro Votorantim e Fábrica de Cimento Rodovalho, além de terrenos em São Paulo e no Paraná) - compuseram o Grupo Votorantim que, liderado por

(8) Os dez maiores grupos econômicos do Brasil em 2007 eram, em ordem crescente de receita bruta (em parênteses o ano de fundação): Fiat (1899), Gerdau (1909), Votorantim (1892), Ambev (1999), Telefônica (1924), Banco do Brasil (1808), Itaú (1945), Vale (1942), Bradesco (1943) e Petrobras (1953) (Aldrighi; Postali, 2010, p. 355-356). Há trabalhos que traçam um histórico dos grupos econômicos brasileiros, mas que não empreenderam análises específicas ao período da primeira metade do século XX, caso de Bonelli (1998) e Gonçalves (1999).

(9) São Paulo (15 fev. 1928, p. 1471. Apesar das buscas junto ao acervo do Centro de Memória Votorantim, da base de dados do Diário Oficial de São Paulo e no acervo do jornal O Estado de São Paulo, não foi possível encontrar as demonstrações de lucros e perdas dos anos subsequentes a 1927, voltando a constar tais demonstrações somente em 1940. Dessa forma, restringimos nossa análise ao ano de 1927, pois é possível que, posteriormente a este ano, os têxteis tenham decrescido sua participação nas receitas do Grupo Votorantim, mas não temos como comprovar esta hipótese. Ademais, como aponta Levy (1994, p. 194-195; 243-244), não havia uma regulamentação sobre como as sociedades anônimas nacionais deveriam apresentar suas demonstrações financeiras. 
Antonio Pereira Ignácio na década de 1920, receberam novos investimentos que permitiram à Fábrica Votorantim tornar-se a maior firma têxtil algodoeira do Estado de São Paulo em 1925 e superar a conjuntura de crise no setor após 1925.

\section{Oanco União de São Paulo e a formação da Fábrica Têxtil Votorantim (1891)}

Em 1892, o estado de São Paulo contabilizava 24 bancos, que juntos tinham ativos que ultrapassavam o valor de 401 mil contos de réis ${ }^{10}$. O maior destes bancos era o União de São Paulo, banco universal ${ }^{11}$ cujo ativo de 112 mil réis representava aproximadamente $28 \%$ do total dos ativos das casas bancárias paulistas em 1892 (Hanley, 2005, p. 155).

O União de São Paulo foi criado em 31 de janeiro de 1890 por Antonio de Lacerda Franco (presidente do banco) ${ }^{12} \mathrm{e}$ João Baptista de Mello Oliveira $^{13}$, membros do grande capital cafeeiro que tinham diversos investimentos na economia paulista, além de importante participação no Partido Republicano Paulista (PRP), assim como seria visto com os demais membros da primeira diretoria do banco $^{14}$. O que diferenciava a atuação do Banco União frente aos seus congêneres, além do privilégio de emissão de moeda que durou entre 1890-1893, era sua carteira de investimentos industriais, que absorvia boa parte de seus ativos (Hanley, 2005, p. 151).

O principal empreendimento industrial do banco se deu no setor têxtil. Em 1890, o União de São Paulo adquiriu a fazenda São Francisco, cujas terras ficavam

(10) A formação de bancos, e também indústrias, no início da República foi impulsionada pelos decretos n. 164 e 165, de 17 de janeiro de 1890, que estimularam as sociedades anônimas com a possibilidade de negociar suas ações apenas com a integralização de $10 \%$ do capital subscrito pelos incorporadores (Tannuri, 1981, p.65).

(11) Sua natureza de banco universal lhe permita realizar: atividades de crédito comercial, como a provisão de empréstimos de curto prazo, descontos e câmbio; atividades de crédito agrícola e hipotecário, como a concessão de financiamentos de longo prazo, garantidos por propriedades imobiliárias rurais ou urbanas, e adiantamentos contra colheitas futuras; crédito industrial para a construção de prédios, ferrovias, docas, melhorias portuárias, comunicações e atividades administrativas, como a propriedade e a operação de interesses industriais (Marcondes Hanley, 2010, p. 112-113).

(12) Antonio de Lacerda Franco, filho de Bento de Lacerda Guimarães (Barão de Araras), foi gerente da casa comissária e exportadora J. F. de Lacerda \& Cia., e senador estadual em 1892, chegando ao senado federal no período entre 1924 e 1930; foi também membro da comissão executiva do PRP entre 1901-1906 e 1914-1927 (Silva, 2011).

(13) João Baptista de Mello Oliveira era importante cafeicultor na região de Rio Claro - SP e foi um dos fundadores do PRP e senador estadual entre 1892-1903 (Silva, 2011, p. 232).

(14) Joaquim Lopes Chaves (senador estadual em 1894 e 1901 e cunhado de Américo Brasiliense, que foi o primeiro presidente do Estado de São Paulo); Antonio Paes de Barros (senador estadual em 1903, filho do Barão de Piracicaba e sobrinho do brigadeiro Rafael Tobias de Aguiar); Bento Quirino dos Santos (vereador por São Paulo e presidente da Companhia Mogiana de Estradas de Ferro); João Tobias de Aguiar e Castro (senador estadual em 1892, filho da Marquesa de Santos e do brigadeiro Rafael Tobias de Aguiar); e Vitoriano Gonçalves Camilo (Silva, 2011, p. 232). 
na cidade paulista de Sorocaba e que continham uma cachoeira conhecida pelos indígenas como Boturantim, origem da futura cidade de Votorantim ${ }^{15}$. Esta queda d'água foi fundamental para viabilizar o fornecimento de energia, pois foram construídas barragens na corredeira do Rio Sorocaba que formaram uma pequena usina hidrelétrica que, a partir de 1892, passou a alimentar a Fábrica de Chitas Votorantim, criada em julho de 1891, unidade têxtil nas terras da fazenda que tingia e estampava tecidos de algodão importados - a chita - sobretudo da Inglaterra (Silva, 2011, p. 233) ${ }^{16}$.

A chegada da matéria-prima e o escoamento da produção foram resolvidos em janeiro de 1893, quando foi inaugurada a Estrada de Ferro Votorantim, que com seus oito quilômetros de extensão interligava a fábrica à cidade de Sorocaba, onde passavam os trilhos da Estrada de Ferro Sorocabana (Efev, p. 1) ${ }^{17}$.

Constituída como uma sociedade em comandita cujo capital era de 1.000 contos de réis (equivalente a 52.572 libras esterlinas do ano de 1894) ${ }^{18}$, a Fábrica Votorantim, entre 1894-1896, tinha como sócios comanditários (cuja participação no capital da firma e nos dividendos está entre parênteses): João Baptista de Mello Oliveira (10\%), Carlos Teixeira de Carvalho (10\%), Antonio Paes de Barros (5\%), Joaquim Franco de Camargo Junior (5\%), Barão de Arary (5\%), Domingos Corrêa de Moraes (5\%) e Manoel Alves Leite Penteado (5\%). Por sua vez, o Banco União de São Paulo (55\%) era o único sócio solidário, que tinha responsabilidade ilimitada pelos débitos da firma com terceiros (Balanços, 1894-1896).

De acordo com a Tabela 1, a casa bancária União de São Paulo era a grande financiadora da Fábrica Têxtil Votorantim, respondendo por 97\% dos débitos no passivo da firma entre os anos 1894-1896. Sobretudo em seus anos iniciais, quando estavam sendo construídas as instalações em Sorocaba, o banco passou a desembolsar grandes somas para a formação de uma nova unidade fabril - em 1904, a Fábrica Votorantim inauguraria sua seção de fiação e tecelagem - que respondia pela totalidade dos gastos do banco na empresa.

(15) A região de Sorocaba, com seu solo arenoso, era propícia ao plantio do algodão, haja vista que, entre 1903-1905, 80\% da produção de algodão paulista vinha daquela região (Carone, 2001, p. 95).

(16) Havia uma preferência por situar as plantas industriais próximas aos rios e suas quedas d'água, que permitiam a construção de pequenas usinas hidrelétricas que alimentariam as fábricas. Isto vinha do fato de que a maior parte da produção energética de São Paulo se destinava ao consumo doméstico (Carone, 2001, p. 81-86).

(17) Inicialmente, a Estrada de Ferro Votorantim contava com 5 locomotivas, 30 vagões de carga, 8 carros de passageiros e 1 carro especial para autoridades, além de 1 carro fúnebre (Efev, p.1).

(18) Convertemos os valores nominais de mil-réis para libras esterlinas a fim de permitir a comparação dos valores em diferentes anos, com base nas cotações apresentadas em http://www.ipeadata.gov.br/. Para a aferição dos valores constantes, eles foram obtidos através da utilização do índice de preços para a Grã-Bretanha elaborado por Mitchell (2007, p. 953-960). 
A formação do Grupo Votorantim: as origens de um grupo econômico brasileiro no setor têxtil ...

Tabela 1

Balanços patrimoniais da Fábrica Têxtil Votorantim, 1894-1896 em libras esterlinas constantes e porcentagem

\begin{tabular}{l|c|c|c}
\hline \multicolumn{1}{c|}{ Anos } & 1894 & 1985 & 1896 \\
\hline Ativo & 209.555 & 243.618 & 226.121 \\
\hline Passivo & 150.831 & 187.612 & 188.359 \\
\hline Patrimônio líquido & 58.671 & 56.006 & 37.762 \\
\hline Dividendos & 4.310 & 1.062 & 14.500 \\
\hline Lucros suspensos & 1.786 & 1.802 & - \\
\hline Lucratividade (em \%) & 10,3 & 5,1 & 38 \\
\hline Banco união (em \% no passivo) & 100 & 100 & 91 \\
\hline
\end{tabular}

Nota 1: a lucratividade é dada pelo quociente de rentabilidade do patrimônio líquido (dividendos + lucros suspensos/patrimônio líquido). Em que pese a haver outros indicadores de lucratividade, a escolha se deu em virtude do quociente de rentabilidade do patrimônio líquido ter sido utilizado por Hanley (2005) para mensurar a lucratividade de bancos como o União de São Paulo, o que permite comparar a lucratividade da Fábrica Têxtil Votorantim com a de seu controlador. Fonte: Balanços, 1894-1896.

De outra parte, o banco União conseguia diversificar suas fontes de rendimento em um setor com boas perspectivas dentro do complexo cafeeiro. Hanley (2005, p. 207) indica que a lucratividade do União de São Paulo entre 1890-1895 teve um valor médio de 4,9\% por semestre e, entre 1895-1899, este valor foi de 3,0\%. Já a Fábrica Votorantim, conforme a Tabela 1, apresentou um lucro quase duas vezes maior nos anos de 1894 e 1895, respectivamente, com 10,3\% e 5,1\%, cifra que chegou a $38 \%$ em 1896, mostrando ser este investimento industrial uma importante fonte de formação e diversificação da riqueza para os acionistas do banco, que veriam a Votorantim se tornar uma das maiores firmas têxteis algodoeiras de São Paulo na década de 1910 (Balanços, 1894-1896).

\section{A Fábrica Votorantim e sua participação na indústria têxtil paulista até a I Guerra Mundial}

Sob os efeitos das políticas contracionistas a partir de 1898, a quantidade de papel-moeda em circulação no Brasil foi drasticamente reduzida entre 1898-1903 em torno de $13 \%$ do estoque - afetando sobremaneira os bancos nacionais, que atravessaram uma crise de grandes proporções em que diversas casas bancárias foram à falência (Fausto, 2006; Franco e Lago, 2012; Delfim Netto, 2009 $)^{19}$. Mesmo na condição de um dos maiores bancos paulistas, o União de São Paulo sofreu os impactos da crise. A partir de 1906, a casa abandonou as operações

(19) Segundo Saes (1986, p. 142) “Até 1906, os níveis monetários de depósitos e empréstimos são inferiores aos de 1899. Sabemos também da liquidação de grande número de bancos nesses anos [...]”. 
comerciais e se fixou na administração de seu portfólio industrial, principalmente, dos negócios da Fábrica Votorantim ${ }^{20}$.

$\mathrm{Na}$ indústria têxtil paulista, sob os efeitos do Plano de Valorização do Café $^{21}$ em 1906, o que se viu foi uma nova onda de investimentos a partir de 1907, em uma conjuntura marcada por maior proteção alfandegária, câmbio estabilizado, maior uso da energia elétrica e expansão populacional - principalmente na capital. A importação de máquinas têxteis para o Brasil entre 1907-1910 mais do que dobrou, permitindo às têxteis paulistas dobrarem seus níveis de produção entre 1907-1913 (Suzigan, 2000, p. 154; Cano, 1981, p. 129; Stein, 1979, p. 108; Brasil, 1946, p. 54).

\section{Tabela 2}

As maiores empresas de tecidos de algodão do Estado de São Paulo em dezembro de 1910, segundo o volume do capital investido - em libras esterlinas constantes

\begin{tabular}{|c|c|c|c|c|c|c|}
\hline $\begin{array}{l}\text { Nome da firma } \\
\text { (Proprietário) }\end{array}$ & Local & $\begin{array}{c}\text { Capital } \\
\text { (em libras } \\
\text { esterlinas) }\end{array}$ & Operários & Teares & Fusos & Produção \\
\hline $\begin{array}{c}\text { Cotonifício Rodolpho } \\
\text { Crespi }\end{array}$ & São Paulo & 436.398 & 1.305 & 500 & 14.000 & $\begin{array}{c}\text { Brins, } \\
\text { cassinetas, } \\
\text { colchas, } \\
\text { atoalhados, } \\
\text { chalés }\end{array}$ \\
\hline $\begin{array}{c}\text { Fábrica Votorantim } \\
\text { (Banco União de São } \\
\text { Paulo) }\end{array}$ & Sorocaba & 363.665 & 812 & 1.109 & 36.000 & $\begin{array}{l}\text { Chitas, } \\
\text { morins, brins }\end{array}$ \\
\hline $\begin{array}{l}\text { Companhia Industrial } \\
\text { de São Paulo }\end{array}$ & São Paulo & 290.931 & 600 & 318 & 11.000 & $\begin{array}{c}\text { Tecidos crus, } \\
\text { xadrez, } \\
\text { riscados }\end{array}$ \\
\hline $\begin{array}{c}\text { Fiação, Tecelagem e } \\
\text { Estamparia Ypiranga } \\
\text { (Nami-Jafet \& } \\
\text { Irmãos) }\end{array}$ & São Paulo & 290.931 & 785 & 444 & 14.000 & $\begin{array}{c}\text { Tecidos crus, } \\
\text { chitas, brins, } \\
\text { lenços }\end{array}$ \\
\hline $\begin{array}{l}\text { Fábrica de Tecidos } \\
\text { São Martinho }\end{array}$ & Tatuí & 269.112 & 374 & 325 & 8.312 & $\begin{array}{c}\text { Tecidos crus, } \\
\text { xadrez, } \\
\text { cobertores }\end{array}$ \\
\hline $\begin{array}{l}\text { Total do Ramo } \\
\text { Algodoeiro } \\
\text { (24 firmas) }\end{array}$ & - & 3.393 .766 & 13.396 & 8.544 & 226.808 & \\
\hline
\end{tabular}

Fonte: Boletim (jul. 1912, p. 308-311).

(20) Hanley (2005, p. 144-151; 207) argumenta que a falência dos bancos universais estava atrelada à sua menor lucratividade frente aos bancos comerciais. A menor lucratividade teria levado os investidores a buscarem os bancos comerciais e também outras formas de investimentos, como ferrovias.

(21) Fausto (2006, p. 237). 
Como demonstra a Tabela 2, o ramo algodoeiro paulista era concentrado em grandes empresas - Cotonifício Rodolpho Crespi, Tecelagem Ypiranga, Companhia Industrial de São Paulo, Fábrica São Martinho e Votorantim - que, somadas, respondiam por $48 \%$ do capital total do ramo, $29 \%$ dos operários, $32 \%$ dos teares e $37 \%$ dos fusos ${ }^{22}$. A Fábrica Votorantim era a segunda maior firma de tecidos de algodão paulista em 1910. A planta industrial na cidade de Sorocaba tinha uma fábrica que ocupava 100 mil metros quadrados e terrenos anexos que atingiam 1 milhão e 800 mil metros quadrados, acrescidos de 1.500 alqueires de terras cultivadas, campos e matas de fazendas que haviam sido adquiridas. Tinha geração energética própria de 2.150 cavalo-vapor de energia hidrelétrica para manufaturar 150 toneladas de algodão mensalmente. Para escoar a produção de tecidos e também do calcário explorado em suas terras - em torno de 30.000 sacos de cal ao mês havia a Estrada de Ferro Votorantim, atendida por quatro locomotivas de 14 toneladas, sete carros de passageiros e 44 vagões de carga, sendo que o trem trafegava 20 quilômetros por dia. Ademais, para os funcionários havia: casas para operários com água encanada, esgotos, luz elétrica, cinema, clube, igreja, campo de esportes e de tênis (Carone, 2001, p. 141).

Entretanto, este cenário expansivo do setor têxtil, a exemplo do que ocorreria com a economia nacional, sofreria os efeitos da I Guerra Mundial (1914-1918), a cambiar o destino do banco União de São Paulo e da Fábrica Votorantim.

\section{A I Guerra Mundial, a falência do banco União de São Paulo e a venda da Fábrica Votorantim (1918)}

Os anos da I Guerra Mundial, entre 1914-1918, foram marcados por um refluxo do comércio internacional. Para a indústria brasileira, em que boa parte dos setores demandava matérias-primas estrangeiras, as cifras de importação destes insumos caíram 52\% frente aos dados de 1911-1913, tendência declinante repetida na importação de combustíveis (-35\%), bens de capital para a indústria (-78\%) e bens de consumo (-55\%) (Villela; Suzigan, 1973, p. 128).

Na seara financeira, a guerra também gerou problemas de grande monta. O banco União de São Paulo, que desde 1906 circunscrevera suas atividades à condução de seus ativos industriais, sofria também no contexto da crise que se abateu de forma concomitante sobre o setor bancário paulista, com a evasão de capitais

(22) A oligopolização não era uma característica apenas do setor têxtil algodoeiro paulista nas duas primeiras décadas do século XX. Realçando a concentração a nível nacional, Stein aponta que seis fábricas na capital federal e duas em São Paulo possuíam mais de dois terços dos fusos, pouco menos de um terço dos teares e em torno de um quinto dos operários têxteis algodoeiros. No Rio de Janeiro, em 1910, as maiores firmas algodoeiras eram: Alliança, Confiança Industrial, Progresso Industrial, América Fabril e Carioca (Stein, 1979, p. 110-114). Ademais, a concentração em grandes empresas era vista também no México que, em 1910-1911, possuía 145 fábricas têxteis, mas apenas 9 destas firmas respondiam aproximadamente $50 \%$ da produção nacional de tecidos, concentradas no Estado de Veracruz e Puebla (King, 2003, p. 257-265). 
estrangeiros, movimento que levou a uma crise de liquidez, evidenciada pela falta de cambiais que culminou com o fechamento da Caixa de Conversão em 1914. Neste cenário, tornava-se mais complicado atender à demanda por capital de giro à manutenção dos negócios da Fábrica Votorantim (Saes, 1986, p. 107; Marcovitch, 2009, p. 235).

A crescente demanda por capitais vinda da Fábrica Votorantim, uma das maiores firmas algodoeiras paulistas no período, coadunava-se à conjuntura positiva do setor têxtil durante o interregno 1914-1918, tanto no mercado paulista quanto nacionalmente. Baseadas nos elevados investimentos em teares e fusos feitos antes da Primeira Guerra Mundial, e tendo uma importante queda nas importações de tecidos de algodão - dada tanto pelas dificuldades no comércio marítimo quanto pelo câmbio desvalorizado - as firmas têxteis nacionais tiveram uma reserva do mercado interno que impulsionou a produção de tecidos de algodão, gerando um cenário favorável que, no caso paulista, permitiu às grandes empresas manter sua posição dominante no ramo (Stein, 1979, p. 116; Suzigan, 2000, p. 157-158; Cano, 1981, p. 175$)^{23}$.

Tabela 3

As maiores empresas de tecidos de algodão do Estado de São Paulo em dezembro de 1916, segundo o volume do capital investido - em libras esterlinas constantes

\begin{tabular}{c|c|c|c|c|c}
\hline Nome da firma (Proprietário) & Local & $\begin{array}{c}\text { Capital (em } \\
\text { libras } \\
\text { esterlinas) }\end{array}$ & Operários & Teares & Fusos \\
\hline $\begin{array}{c}\text { Cotonifício Rodolpho Crespi } \\
\text { Fábrica Votorantim (Pereira } \\
\text { Ignácio \& Cia.) }\end{array}$ & Copital & 529.608 & 2.000 & 700 & 20.000 \\
\hline $\begin{array}{c}\text { Fiação, Tecelagem e } \\
\text { Estamparia Ypiranga (Nami- } \\
\text { Jafet \& Irmãos) }\end{array}$ & Capital & 242.494 & 1.000 & 650 & 18.000 \\
\hline $\begin{array}{c}\text { Mariangela (Indústrias } \\
\text { Reunidas Francisco } \\
\text { Matarazzo) }\end{array}$ & Capital & 198.404 & 1.900 & 1.465 & 40.000 \\
\hline $\begin{array}{c}\text { Fábrica de Tecidos São } \\
\text { Martinho }\end{array}$ & Tatuí & 156.298 & 476 & 401 & 6.724 \\
\hline $\begin{array}{c}\text { Total do Setor Algodoeiro (44 } \\
\text { firmas) }\end{array}$ & - & 3.898 .341 & 21.216 & 13.882 & 412.077 \\
\hline
\end{tabular}

Fonte: Boletim (ago./set. 1918, p. 387.

(23) A produção nacional de tecidos de algodão em 1919 era $47 \%$ maior do que em 1912, sendo que 75\% do consumo nacional de tecidos de algodão eram abastecidos por firmas nacionais que, inclusive, teriam exportado para Argentina e Uruguai. Em relação ao Estado de São Paulo, as firmas algodoeiras, que haviam produzido 83 milhões de metros de tecidos em 1913, aumentaram esta cifra para 147 milhões de metros em 1918 e, no ano seguinte, para 175 milhões de metros de tecidos; ao passo que, as importações de tecidos de algodão através do Porto de Santos caíram 62\% nos anos da I Guerra Mundial (Suzigan, 2000, p. 154; Stein, 1979, p. 116; Cano, 1981, p. 293; Dean, 1971, p. 98). 
Analisando a Tabela 3, vemos que, em relação à amostra de empresas de 1910 (Tabela 2), eram quase que as mesmas grandes firmas a controlar o setor têxtil paulista - incluindo-se agora as Indústrias Reunidas Francisco Matarazzo no lugar da Companhia Industrial de São Paulo - e com uma participação no setor semelhante ao período anterior: agora elas detinham $40 \%$ do capital do ramo, $32 \%$ dos operários, $31 \%$ dos teares e $17 \%$ dos fusos - em 1910, as cinco maiores firmas possuíam $37 \%$ dos fusos. Ademais, o capital empregado no ramo algodoeiro tinha aumentado $15 \%$, elevação expressa pela ampliação da capacidade produtiva, pois em 1916, o número de teares, fusos e operários havia quase duplicado ${ }^{24}$.

De outra parte, notamos que a solução encontrada pelo Banco União, em dificuldades financeiras, foi arrendar a condução da Fábrica Votorantim em 1914 a um terceiro com capitais e experiência no setor algodoeiro, o empresário português Antonio Pereira Ignácio, que na Tabela 3 aparece como proprietário da Votorantim $^{25}$. A firma Pereira Ignácio \& Cia. era a reunião das várias unidades descaroçadoras de algodão que o empresário português possuía - na cidade paulista de Tietê, Laranjal Paulista, Itu, Conchas, Botucatu, Bofete -, extraindo delas o óleo e a pluma de algodão, o que fizera dele o principal fornecedor da Fábrica Votorantim (Carone, 2001, p. 94).

Para ele, o arrendamento mostrava-se uma ótima oportunidade de integração vertical de seus investimentos, uma vez que, Pereira Ignácio controlaria o fornecimento da matéria-prima (algodão) e a fabricação dos tecidos de algodão, integrando os elos da cadeia têxtil ${ }^{26}$. Aliás, tratava-se a Fábrica Votorantim da segunda maior firma têxtil paulista, com uma importante gama de recursos produtivos - fornecimento de energia próprio, ferrovia particular - que lhe proporcionavam relevantes vantagens competitivas no setor em que Pereira Ignácio

(24) Ao analisarmos a base de dados do Boletim da Diretoria de Indústria e Comércio do estado de São Paulo, constatamos a inexistência de dados sobre a indústria têxtil algodoeira referente aos anos de 1913 e 1914. Dessa forma, em que pese aos dados da tabela 3 comprovarem o aumento no número de teares e fusos das firmas têxteis, é importante considerar que este acréscimo pode ter ocorrido antes da Primeira Guerra Mundial, quando o fluxo de importações de maquinário de têxtil ainda era grande, como apontado por Stein $(1979$, p. 195) e Suzigan (2000, p. 157).

(25) Antonio Pereira Ignacio saiu de Portugal em 1884 e migrou para a região de Sorocaba aos 10 anos de idade. Filho de um sapateiro, ele completou seus estudos ginasiais e foi trabalhar na firma de importação de tecidos de João Reinaldo de Faria, na cidade do Rio de Janeiro. A experiência na casa importadora lhe proporcionou a acumulação de um capital inicial que foi investido posteriormente, na década de 1890, na formação de armazéns de secos e molhados no interior de São Paulo. Entre 1901 e 1904, ele abriu três firmas que descaroçavam a fibra de algodão na região de Sorocaba. Recorrendo aos capitais do antigo patrão e aos contatos adquiridos em uma estadia nos Estados Unidos trabalhando em uma indústria têxtil no Alabama, Antonio formou a Fábrica de Óleos Santa Helena em 1905, na cidade de Sorocaba, com máquinas estadunidenses (Dean, 1971, p. 60-61; Caldeira, 2007, p. 11-14).

(26) Segundo Chandler (1998, p. 332) “[...] quanto mais concentradas as unidades de produção e quanto mais concentradas as fontes de suprimento, maior a probabilidade de integração das duas numa só empresa". 
possuía outras duas firmas de tecelagem ${ }^{27}$. Ademais, a Fábrica Votorantim apresentava-se como uma firma em evolução no período 1910-1916 - como demonstra a comparação das Tabelas 2 e 3 -, pois no interregno ela aumentou seu capital em $21 \%$ e contratou mais operários, mantendo-se o número de teares e fusos. Por tudo isso, se de fato havia uma crise no setor financeiro nacional que afetava o Banco União, ou mesmo problemas no ramo algodoeiro, estas adversidades não parecem ter atingido o cotidiano da Fábrica Votorantim em um primeiro momento ${ }^{28}$.

Todavia, um incêndio atingiu as instalações da Fábrica Votorantim, descrito em 26 de fevereiro pelo jornal sorocabano Cruzeiro do $\mathrm{Sul}^{29}$. Os prejuízos do incêndio chegaram a 1.000 contos de réis (36.115 libras esterlinas constantes) apenas $24 \%$ deste valor seria restituído pelo seguro - e foram um duro golpe em seu já debilitado mantenedor, o banco União de São Paulo, que devido às tribulações financeiras se encontrava em débito com os funcionários da fábrica, que decidiram paralisar as atividades em junho de 1917, em meio ao movimento da Greve Geral (Jornal Cruzeiro do Sul, 17 jul. 1917, p. 01 apud Dessotti, 2006) ${ }^{30}$.

(27) Dentre as 46 empresas têxteis algodoeiras do Estado de São Paulo em dezembro de 1917, o português consta como proprietário da fábrica Lusitânia, localizada na cidade de São Paulo, com capital de 49.441 libras esterlinas constantes, 900 operários, 378 teares e 11.380 fusos; além desta, ele era proprietário da fábrica Lucinda (antiga São Bernardo Fabril), localizada em São Bernardo, com capital de 44.096 libras constantes, 635 operários, 377 teares e 14.432 fusos (Boletim, mar./abr., 1919, p. 120).

(28) Em 1916, no Estado de São Paulo as seguintes firmas têxteis algodoeiras tiveram suas atividades suspensas (em parênteses o local da fábrica e o capital da empresa em libras esterlinas constantes): São Bernardo Fabril (São Bernardo - SP, 154.314 libras esterlinas), Companhia Fabril Paulistana (Capital, 88.180 libras), J. Brenha \& C. (São Roque - SP, 26.454 libras), Cia. Nacional de Tecelagem (Capital, 13.226 libras) e Santa Irinéa (Capital, 8.818 libras). E, em 1917, a Fábrica Arethusina (Piracicaba - SP, 46.886 libras) e a J. Brenha \& C. (São Roque SP, 46.886 libras) (Boletim, ago./set., 1918, p. 387; mar./abr. 1919, p. 120).

(29) "Arde um deposito de algodão da Fabrica de Tecidos de Votorantim. Os prejuizos aproximam-se de mil contos de reis. O incendio começou as $18 \mathrm{~h} 45 \mathrm{~min}$ só foi contido de madrugada quando o corpo de bombeiros chegou. A fabrica de tecidos Votorantim pertence ao Banco União de São Paulo é um dos estabelecimentos industriaes de maior importância do Estado. Possue cerca de 1200 teares e neles trabalham calculadamente 3 mil operarios. No deposito existiam 3200 fardos de algodão, muitas barricas de soda caustica e potassa, grande quantidade de farinha de trigo; enumeras botijas de ácido para preparação de tinta etc. O fogo tomou proporções assustadoras. A população de Votorantim, composta em quasi sua totalidade de operarios affluiu ao logar do incêndio rapidamente tentando dominar as chamas, luctando com grande dificuldade por falta de numero suficiente de mangueiras e aparelhos extinctores de incendio no deposito. Do inquerito aberto ficou constatado que o incendio não foi proposital, sendo o mesmo atribuido a alguma fagulha desprendida por uma locomotiva fagulha esta que penetrou por abertura situada na parte superior do barracão. Os prejuizos subiram a quase 1000 contos de réis, estando o deposito de algodão da referida fábrica de tecidos seguro em 240 contos de réis" (Jornal Cruzeiro do Sul apud http://www.ihggs.org.br/?option=content\&task=view\&id=204\&Itemid=76\&limit=1\&limitstart=4). Acesso em: 3 mar. 2015.

(30) A Greve Geral atingiu importantes firmas têxteis algodoeiras paulistas, como a maior destas empresas, o Cotonifício Crespi, que contava 1.305 operários, dos quais 400 decidiram entrar em greve em junho de 1917 ao ver negado o pedido de reajuste salarial entre $15 \%$ e $20 \%$, além da negativa dos patrões em abolir a extensão da carga horária noturna (Biondi, 2009, p. 263-306). 
A formação do Grupo Votorantim: as origens de um grupo econômico brasileiro no setor têxtil ...

Tabela 4

Balanço da Fábrica Votorantim em 31 de janeiro de 1918 - em libras esterlinas correntes

\begin{tabular}{l|c|l|c}
\hline \multicolumn{2}{c|}{ Ativo (em libras esterlinas) } & \multicolumn{2}{c}{ Passivo (em libras esterlinas) } \\
\hline $\begin{array}{l}\text { Banco União de São Paulo } \\
\text { (conta de penhor) }\end{array}$ & 56.875 & $\begin{array}{l}\text { Banco União de São Paulo } \\
\text { (conta de arrendamento) }\end{array}$ & 22.641 \\
\hline Arrendamento da Fábrica & 30.008 & Garantias diversas & 57.958 \\
\hline Mercadorias em penhor & 57.958 & Serviços médicos & 54 \\
\hline Almoxarifado & 59.583 & Letras a pagar & 40.191 \\
\hline Maquinismos & 758 & Folha de pagamento & 5.037 \\
\hline Móveis e utensílios & 108 & Lucros e perdas & 55.683 \\
\hline Construções & 487 & Contas correntes (credores) & 105.679 \\
\hline Selos de consumo & 216 & & \\
\hline Combustível & 108 & & 287.243 \\
\hline Caixa de Votorantim & 1.300 & & \\
\hline Algodão & 24.916 & & \\
\hline Letras a receber & 7.583 & & \\
\hline Sinistros a liquidar & 27.191 & & \\
\hline Contas correntes (devedores) & 20.041 & & \\
\hline Total Ativo & 287.132 & Total Passivo & \\
\hline Obs.: a discordânia entre os & & & \\
\hline
\end{tabular}

Obs.: a discordância entre os números do Ativo e do Passivo se deve ao arredondamento dos valores das referidas contas.

Fonte: SAFV (1918-1919, p. 3-5).

No ano de 1917, a administração da Fábrica Votorantim ficou a cargo de Antonio Pereira Ignácio, que arrendara a unidade têxtil junto ao banco União de São Paulo e conseguiu reabrí-la ainda em julho daquele ano, junto com o empresário Nicolau Scarpa que, somados, detinham 93\% dos valores que a Fábrica Votorantim devia aos seus credores em conta corrente: Scarpa tinha a receber $15 \%$ dos créditos em conta corrente da Votorantim e, por sua vez, Pereira Ignácio era credor de 78\% de tais valores ${ }^{31}$. Conforme a Tabela 4 acima, que demonstra o resultado financeiro da Fábrica Votorantim do ano de 1917, no lado do ativo, nota-se que a maioria dos ativos da Fábrica Votorantim encontrava-se imobilizada, uma vez que $61 \%$ dos valores eram representados pela soma das contas Banco União de São Paulo (conta de penhor), Mercadorias em penhor e Almoxarifado; enquanto que, os Devedores em Conta Corrente e as Letras a Receber significavam apenas 10\% do ativo, a

(31) A bibliografia (Dessotti, 2006; Caldeira, 2007; Marcovitch, 2009) aponta que o empresário italiano Nicolau Scarpa, através da firma Francisco Scarpa \& Filho, também seria arrendatário da Fábrica Votorantim. Porém, no primeiro balanço financeiro exposto no Livro Diário da Fábrica Votorantim referente a 17 de janeiro de 1918, consta nos débitos e créditos apenas o nome da firma Pereira Ignácio \& Cia., o que nos permite afirmar que quem de fato comandava os negócios da empresa era Antonio Pereira Ignácio, auxiliado por Nicolau Scarpa. 
demonstrar que os valores a receber de terceiros pelo arrendatário não eram tão elevados ${ }^{32}$.

De outra parte, vemos que a conta Lucros e Perdas respondia por $20 \%$ do passivo da firma em 1917, valor relevante e que representava $10 \%$ do capital declarado pela Votorantim em 1916 (Tabela 3). Porém, se do Passivo excluirmos a conta Garantias Diversas que tinha seu valor correspondente na conta Mercadorias em Penhor (Ativo), constatamos que a situação financeira da fábrica têxtil sorocabana não era tão solvente, pois a soma das contas Letras a Pagar e Credores em Conta Corrente alcançava $64 \%$ dos passivos, ou seja, cifra cinco vezes maior do que os valores que a empresa tinha a receber. Ademais, a situação era ainda desfavorável ao arrendatário, pois do valor total dos Credores em Conta Corrente, a Pereira Ignácio \& Cia. tinha 86.450 libras esterlinas para serem quitadas pela Fábrica Votorantim, o equivalente a $78 \%$ dos débitos ${ }^{33}$.

Ao final de 1917, de um lado havia o banco União de São Paulo atravessando sérias dificuldades financeiras, mas ainda detentor de uma das maiores fábricas têxteis de São Paulo, além de outros ativos ${ }^{34}$. De outra parte, os empresários Pereira Ignácio e Nicolau Scarpa eram os principais credores da Votorantim e com interesses no setor têxtil paulista ${ }^{35}$. A solução deste impasse ocorreu em sete de janeiro de 1918, quando um leilão na cidade de São Paulo marcou a falência do banco União de São Paulo e a arrematação de seu espólio por Pereira Ignácio, Nicolau Scarpa e outros participantes minoritários pelo valor de 5 mil contos de réis (180.180 libras esterlinas constantes) $)^{36}$.

(32) Nas Contas Correntes da Fábrica Votorantim apareciam os seguintes devedores (valores a pagar em libras esterlinas correntes): Byington \& Cia. (162); Joaquim Soares Fernandes (108); Elias Domingos \& Cia. (433); Sampaio Moreira, Filho \& Cia. (1.245); Martins Costa \& Cia. (4.604); Assad Abdala \& Nagib Salem (162); João Reynaldo Coutinho \& Cia. (108); Fernando Costa \& Cia. (108); Nami Jafet \& Irmãos (6.662); Araújo Costa \& Cia. (866); J. Moreira \& Cia. (108); Affonso Viseu \& Cia. (1.408); Massa Falida do Banco União (3.575).

(33) Nas Contas Correntes da Fábrica Votorantim apareciam os seguintes credores (valores a receber em libras esterlinas): Continental Products \& C. (54); Henry Rogers, Sons \& Cia. (487); Societé Financiére e Commerciale Franco Brésilienne (54); Schill \& Cia. (54); Francisco Gagliardi (54); E. Vella (1.354); Companhia Mechanica e Importadora de São Paulo (433); Indústrias Reunidas Francisco Matarazzo (487); Francisco Scarpa \& Filho (11.266); Naegeli \& Cia. (920); Pereira Ignácio \& Cia. (86.450); Carlo Crespi \& Cia. (1.300); Pires Fontoura \& Cia. (54); Richard Wichello \& Cia. (108); Wilson, Sons \& Cia. (108); Dr. Fred Gifford (108); Lidgerwood Limited (162); Antonio Ciamero (108); Siesel Brothers (1.029); J. Monteiro \& Cia. (108); Eduardo Horn (54); Companhia General Electric (54).

(34) As causas que levaram o banco União de São Paulo à condição falimentar são incertas. Marcovitch (2009, p. 138-139) indica que o banco teria se alavancado em excesso com a execução de projetos imobiliários e industriais que se mostraram frustrados, em virtude do desconhecimento de seus diretores sobre estas obras.

(35) Nicolau trabalhava em conjunto com seu pai Francisco na F. Scarpa \& Filho, casa importadora de gêneros diversos, que tinha um armazém dentro das instalações da Fábrica Votorantim para atender os funcionários da firma sorocabana. Ademais, também atuava no descaroçamento de algodão na região de Sorocaba (Carone, 2001, p. 188; Lloyd et. al., 1913, p. 651).

(36) Os outros compradores minoritários do espólio do banco União de São Paulo foram: José de Cunto e João Cancio Pereira que moravam em São Paulo - SP; João Soares Hungria que morava em Itapetininga -SP; Domingos Piccirillo, Roque de Cunto, José Ventura Fernandes da Silva e Raphael de Cunto que moravam em Sorocaba-SP (Escritura, 1918, p. 1-2). 
A formação do Grupo Votorantim: as origens de um grupo econômico brasileiro no setor têxtil ...

Tabela 5

Descrição dos bens arrematados no leilão do banco União de São Paulo em 07 de janeiro de 1918 valores em contos de réis correntes

\begin{tabular}{l|c}
\hline \multicolumn{1}{c|}{ Composição dos bens } & Valor de Arrematação (contos de réis) \\
\hline $\begin{array}{l}\text { Fábrica, seu terreno, edifício, maquinismos, acessórios, } \\
\text { pertences e sobressalentes; e mais a Via Férrea } \\
\text { compreendendo todas as suas estações, material fixo e } \\
\text { rodante }\end{array}$ & 1.650 \\
\hline $\begin{array}{l}\text { Terreno na cidade de São Paulo (bairro de Santo Amaro), } \\
\text { terreno na cidade de São Bernardo; a Fazenda }\end{array}$ & 95 \\
$\begin{array}{l}\text { Itupararanga (Sorocaba -SP) com seus fornos para a } \\
\text { fabricação de cal e inclusive a fazenda Lagoa que dela é } \\
\text { dependência }\end{array}$ & \\
\hline $\begin{array}{l}\text { Fazenda São Francisco (Sorocaba - SP); terreno na cidade } \\
\text { de São Paulo (Alameda Barão do Rio Branco n. 120) }\end{array}$ & 100 \\
\hline $\begin{array}{l}\text { Parte da fazenda Água Sumida (Ribeirão Bonito - SP); um } \\
\text { terreno no bairro do Jabaquara (São Paulo - SP); } 34 \text { lotes } \\
\text { de terrenos em Curitiba - PR; um terreno no distrito de } \\
\text { Bom Sucesso (Paraná); } 3 \text { ilhas em Paranaguá - PR; }\end{array}$ & 102 \\
\hline Direitos sobre as dívidas ativas do Banco União & 2.335 \\
\hline $\begin{array}{l}\text { Mercadorias, móveis e objetos dados como garantia } \\
\text { penhor mercantil em favor de Pereira Ignácio \& Cia. }\end{array}$ & 95 \\
\hline $\begin{array}{l}\text { 1 milhão de metros de pano dados em penhor mercantil } \\
\text { em favor do Banco do Comércio e Indústria de São Paulo } \\
\text { para garantia de um crédito em conta corrente }\end{array}$ & 5.000 \\
\hline $\begin{array}{l}\text { Objetos e utensílios do escritório do Banco União de São } \\
\text { Paulo na cidade de São Paulo e mais as despesas gerais de } \\
\text { incorporação da Sociedade, inclusive sisas e transcrição } \\
\text { da aquisição dos bens }\end{array}$ & 100 \\
\hline Valor total dos bens & \\
\hline \begin{tabular}{l} 
Fon SAFV (1918-1919, p. 1-2). \\
\hline
\end{tabular} & \\
\hline
\end{tabular}

Fonte: SAFV (1918-1919, p. 1-2).

O Banco União de São Paulo usou o valor levantado no leilão para quitar seus débitos junto aos credores, principalmente com seus debenturistas; o banco do Comércio e Indústria do Estado de São Paulo; a firma Francisco Scarpa \& Filho; e a Pereira Ignácio \& $\mathrm{Cia}^{37}$. Já os adquirentes do espólio valeram-se das dificuldades

(37) No processo de rateio dos valores levantados no leilão, conduzido pelo liquidatário Nicolau Scarpa, os valores se dividiram da seguinte forma (em libras esterlinas correntes): garantias aos debenturistas por hipoteca inscrita (89.375 libras), garantia hipotecária em favor do banco do Comércio e Indústria do Estado de São Paulo (5.145 libras), garantia hipotecária em favor de Francisco Scarpa \& Filho e que apenas dava para o pagamento da primeira hipoteca (5.416 libras), penhor instituído em favor do Banco do Comércio e Indústria de São Paulo (5.416 libras), pagamento do penhor de Pereira Ignácio \& Cia. (5145 libras). Em março de 1918, havia 46.997 debêntures do banco União de São Paulo em circulação e cada um destes títulos dava o direito de receber Rs. $36 \$ 081$ (1,95 libras esterlinas correntes) a ser pago no dia primeiro de abril de 1918 (São Paulo, 24 mar. 1918, p. 1923). 
financeiras daquela instituição para obter bens e direitos sobre uma vasta gama de recursos produtivos por um valor que pode ser considerado subestimado. Julgando que, havia aproximadamente um ano, em dezembro de 1916, somente o capital da Fábrica Votorantim era de 440 mil libras; Pereira Ignácio, Scarpa e os outros compradores despenderam $54 \%$ deste valor para arrematar a fábrica, sua ferrovia e os demais bens pertencentes ao banco ${ }^{38}$.

Analisando a escritura de constituição da Sociedade Anônima Fábrica Votorantim, documento que descreve detalhadamente os bens leiloados em janeiro de 1918 pelo Banco União, vemos que a Fábrica Votorantim em Sorocaba - SP ocupava uma área de 1.070.000 metros quadrados, onde se encontravam fusos, teares, motores elétricos, turbinas e outras máquinas - na maioria importada - que se dividiam entre as seções de tecelagem, fiação, estamparia, acabamento, descaroçamento, oficinas, tinturaria, fundição e de caldeiras, além do depósito de algodão. A Estrada de Ferro Votorantim, cuja concessão foi feita pela Câmara Municipal sorocabana, atravessava a fábrica e tinha o total de 20 quilômetros de extensão, com três estações (Votorantim, Itupararanga e Sorocaba) em que circulavam 7 vagões para passageiros e 13 vagões de carga, além de 21 caixões. $O$ terreno em Santo Amaro, que ficava na cidade de São Paulo e foi comprado pelo Banco União em junho de 1898, tinha área total de 1.177.107 metros quadrados, margeava a linha de bondes da capital e nele possuía olarias. A Fazenda do Itupararanga, na cidade de Sorocaba - SP, tinha nas suas terras jazidas de mármore, pedreiras para a extração e fabricação de cal, em uma área de 13.552 .000 metros quadrados (Escritura, 1918, p. 1-13).

Estes ativos se mostrariam de suma importância à retomada dos negócios da Votorantim a partir de 1918, quando a unidade têxtil e os demais ativos adquiridos formariam a Sociedade Anônima Fábrica Votorantim - doravante, o Grupo Votorantim.

\section{Sociedade Anônima Fábrica Votorantim (1918-1927): o grupo econômico liderado por Antonio Pereira Ignácio}

Em 15 de janeiro de 1918, mesmo dia em que se registrou a escritura de aquisição dos bens leiloados pelo Banco União, estes ativos serviram para formar a Sociedade Anônima Fábrica Votorantim, com sede na cidade de São Paulo - SP. A duração prevista da empresa seria de trinta anos e a finalidade era: 1) indústria de fiação, tecelagem e estamparia de algodão, e outros materiais têxteis na Fábrica

(38) Segundo Marcovitch (2009, p. 235), o patrimônio do Banco União de São Paulo valeria de fato oito vezes mais do que o alcançado no leilão. Para Penrose (2006, p. 244), a falta de liquidez de uma empresa pode levar a subestimação de seu valor pelo mercado, o que pode ter acontecido no caso do banco União de São Paulo. 
Votorantim (Sorocaba - SP), bem como o comércio destes produtos; 2) exploração industrial e comercial das jazidas de calcário nas suas propriedades, as Caieiras de Itupararanga (Sorocaba - SP) e; 3) exploração da Estrada de Ferro Votorantim (Escritura, 1918, p. 13-19).

O capital da empresa era de 5 mil contos (180.180 libras esterlinas), já integralizados e divididos em 25.000 ações de valor nominal de 200 mil réis cada uma, sendo que cada 5 ações, dava direito a um voto nas assembleias gerais. A sociedade seria administrada por dois diretores - Antonio Pereira Ignácio e Nicolau Scarpa - que receberiam para a função 2 contos de réis cada um, mais $10 \%$ sobre o lucro líquido anual (SAFV, 1918-1919, p. 5).

Esta composição diretiva da S. A. Fábrica Votorantim não se estendeu por muito tempo. Em 21 de abril de 1918, Francisco Scarpa faleceu em um acidente ferroviário na E. F. Votorantim, fato que agravou as constantes brigas entre Pereira Ignácio e Nicolau Scarpa, filho de Francisco. No ano seguinte, Scarpa vendeu sua participação acionária na Votorantim para Antonio Pereira Ignácio pelo valor de 2 mil contos de réis (108.333 libras), mais a cessão da Fábrica de Óleos Santa Helena (Marcovitch, 2009, p. 236).

Este passo no controle acionário da Votorantim foi complementado por Pereira Ignácio em maio de 1919, quando ele adquiriu a maioria das ações da empresa que estavam nas mãos dos acionistas minoritários (Caldeira, 2007, p. 28). A partir deste momento, Pereira Ignácio concentrou seus negócios no ramo algodoeiro - empresas descaroçadoras de algodão entre Sorocaba e Piracicaba colocando-os como ativos da Votorantim, em um movimento de integração vertical que lhe permitia controlar do acesso à matéria-prima até a elaboração final dos tecidos.

Ao mesmo tempo, Antonio, um dos mais ricos empresários paulistas no período, já havia adquirido a Companhia Telefônica Sul Paulista e era também dono da Fábrica de Cimento Rodovalho (Marcovitch, 2009, p. 234) ${ }^{39}$. Este último investimento era administrado através da Pereira Ignácio \& Cia. e, assim como as unidades descaroçadoras de algodão, foi agregado aos ativos da S. A. Fábrica Votorantim, transformando-a em uma estrutura empresarial diversificada que se configurou em grupo econômico, o Grupo Votorantim, como mostra a Tabela 6.

(39) Criada em 1892 pelo comendador Antonio Proost Rodovalho, a Fábrica de Cimento Rodovalho estava instalada nas terras da Fazenda Santo Antonio, próximo a Sorocaba e São Roque, onde existiam reservas de calcário. No começo do século XX, a fábrica foi comprada por Antonio Pereira Ignacio. A Usina Rodovalho funcionou até 1904, produzindo o cimento "Santo Antonio". Retornou à atividade em 1907, lançando no mercado os produtos com as marcas "Lage", "Torquês" e "Meia Lua". 
Tabela 6

Empresas componentes da Sociedade Anônima Fábrica Votorantim, 1918-1924

\begin{tabular}{c|c|c|c}
\hline Nome da empresa & Ano de criação & Cidade & Produção/Finalidade \\
\hline Fábrica Votorantim & 1892 & Votorantim (SP) & tecidos de algodão \\
\hline Fábrica Rodovalho & 1892 & São Roque (SP) & Cimento \\
\hline Caieiras de Itupararanga & Desconhecido & Sorocaba (SP) & Cal \\
\hline $\begin{array}{c}\text { Estrada de Ferro } \\
\text { Elétrica Votorantim }\end{array}$ & 1893 & Sorocaba (SP) & Transporte \\
\hline
\end{tabular}

Fonte: São Paulo (30 jun. 1922, p. 1922; 15 fev. 1923, p. 1923; 14 fev. 1925).

O setor têxtil nacional viveria entre o fim da I Guerra Mundial até 1925 uma nova onda de investimentos que se traduziu na aquisição intensa de maquinário importado, calcada nos lucros acumulados durante a guerra e na desorganização econômica dos países europeus após o conflito, visto que a chegada de tecidos de algodão importados só cresceria de maneira mais robusta após 1925. Neste cenário de menor concorrência com produtos estrangeiros, as fábricas têxteis nacionais importaram dez vezes mais maquinário entre 1921-1926, comparado ao período 1914-1920, podendo modernizar suas unidades produtivas e, no caso do setor têxtil paulista, aumentar seus níveis de produção (Suzigan, 2000, p. 159; Stein, 1979, p. $117-120)^{40}$.

O Grupo Votorantim também executou um processo de modernização de seus investimentos no início dos anos 1920, período em que Antonio Pereira Ignácio era seu diretor-presidente ${ }^{41}$. Para a Fábrica Votorantim (unidade têxtil) foram importadas máquinas, ampliadas as dependências da fábrica e feitos aprimoramentos técnicos que permitiam aumentar a produção em $26 \%$ e, ao mesmo tempo, poupar $20 \%$ de mão-de-obra. Estas melhorias possibilitaram à fábrica sorocabana expandir sua produção, que no ano de 1918 foi de 12.921 .635 metros de tecidos de algodão, e passou para 24.023.622 metros em 1923 (SAFV, 1923, p. 2-3).

Em relação à Estrada de Ferro Votorantim, que interligava a fábrica têxtil até Sorocaba, ela teve sua bitola alargada e foi eletrificada, no dia 04 de fevereiro de 1922, mesma data em que foram inauguradas as estações de Paula Souza (Sorocaba, SP) e Santa Helena, que margeava a Fábrica de Cimento Rodovalho. Tais

(40) A produção nacional de tecidos de algodão em 1920 foi de 587.182.000 metros de tecido, número que regrediu para 535.909.000 metros em 1925. No Estado de São Paulo, por sua vez, a produção de tecidos de algodão, que foi de 186.500.000 metros de tecido em 1920, atingiu a marca de 205.900 .000 metros em 1925 (Cano, 1981, p. 292; Stein, 1979, p. 192).

(41) Em fevereiro de 1924, Antonio Pereira Ignácio controlava 99,44\% das 25.000 ações do Grupo Votorantim, com 12.500 ações em seu nome e mais 12.360 ações em nome de sua firma Pereira Ignacio \& Cia; os outros acionistas eram: Paulo Pereira Ignácio (diretor-tesoureiro), Zeferino de Freitas Guimarães (diretor-gerente), Antonio Oliveira Penteado (diretor-comercial), A. de Carvalho e Silva, Jorge Nielsen, Mario Goulart de Faria, sendo que cada um possuía 20 ações (Ata, 1922; SAFV, 1923, p. 13). 
aprimoramentos resultaram em ganhos substanciais no fluxo de passageiros, mercadorias e operários, fazendo com que a renda da ferrovia, que havia sido de 6.987 libras em 1918, alcançasse a cifra de 11.857 libras em 1923 (SAFV, 1923, p. 5 ; Efev, p. 1$)^{42}$.

Também as Caieiras de Itupararanga receberam novos investimentos, com a construção de fornos que permitiram dobrar a produção, que foi elevada para 70 mil sacos (de $50 \mathrm{~kg}$ ) de cal ao mês. Segundo o Relatório da Diretoria do Grupo Votorantim para o ano de 1922, a cal sorocabana tinha boa aceitação no mercado em virtude de ser mais clara, hidráulica e não deixar resíduos (São Paulo, 15 ago. 1922, p. 5429).

Para efetuar as melhorias, conforme a Tabela 7, o Grupo Votorantim (têxtil e demais atividades) valeu-se de duas fontes de financiamentos: os capitais de terceiros (que representavam $61 \%$ do ativo total) e os capitais próprios (que participavam com $39 \%$ do ativo total) ${ }^{43}$. Os financiamentos de terceiros tinham como principal fonte os empréstimos hipotecários que totalizavam $90 \%$ de tais créditos, sendo que havia também os empréstimos com base na caução de títulos e debêntures. Estes empréstimos calcavam-se no elevado montante do capital da Votorantim que se encontrava imobilizado - um valor equivalente a $107 \%$ do patrimônio líquido - e que poderia servir como garantia aos empréstimos tomados ${ }^{44}$.

Tabela 7

Balanços Patrimoniais da S. A. Fábrica Votorantim, 1922-1924 - em libras esterlinas constantes

\begin{tabular}{l|c|c|c}
\hline \multicolumn{1}{c|}{ Anos } & 1922 & 1923 & 1924 \\
\hline Ativo Circulante & 692.713 & 802.880 & 744.570 \\
\hline Caixa & 1.784 & 3.394 & 1.803 \\
\hline Venda de terrenos & 63.672 & 50.315 & 56.311 \\
\hline Selos de consumo & & & 41 \\
\hline Devedores diversos & 339.466 & 380.967 & 211.967 \\
\hline Clientes (Letras a receber) & 130.733 & 142.351 & 194.939 \\
\hline Caução dos diretores & 1.552 & 1.552 & 1.639 \\
\hline $\begin{array}{l}\text { Estoque de mercadorias e manufaturas nos } \\
\text { almoxarifados }\end{array}$ & 152.250 & 224.302 & 277.869 \\
\hline
\end{tabular}

Continua...

(42) Em 1918, o número de passageiros da Estrada de Ferro Votorantim foi de 62.087 pessoas, foram transportadas 69.054 toneladas de mercadorias, além de 40.241 operários. Já em 1923, o número de passageiros chegou a 174.122 pessoas, 948.829 toneladas de mercadorias e 84.212 operários (SAFV, 1923, p. 5).

(43) $\mathrm{O}$ indicador da porcentagem de capitais de terceiros é dado pela razão do passivo circulante dividido pelo ativo total. Já a porcentagem de capital próprio é dada pela razão do patrimônio líquido dividido pelo ativo total.

(44) Marcondes (2014, p. 769) demonstra que o número de empréstimos hipotecários no Estado de São Paulo dobrou nos anos 1920, em relação a 1913, bem como houve aumento no valor das hipotecas. 
Conforme a Tabela 7, vemos que, em meio ao seu processo de modernização das instalações, o Grupo Votorantim apresentava nos anos iniciais da década de 1920 uma boa condição de solvência, com um quociente de cobertura total de 1,653 no período 1922-1924, indicando que o grupo tinha ativos que possibilitavam quitar suas dívidas no longo prazo. Ademais, a liquidez corrente era da ordem de 0,967 , a demonstrar que, no curto prazo, a dívida do grupo também exibia condição de solvência ${ }^{45}$.

Os indicadores de rentabilidade do Grupo Votorantim entre 1922-1924 demonstram que os lucros estavam em expansão, pois a rentabilidade média do patrimônio líquido foi de $42,5 \%$ e a rentabilidade média do ativo era de $17 \%$ no triênio $^{46}$. Estes números exibem a sincronia entre o crescimento do setor têxtil paulista na primeira metade da década de 1920, momento de reaparelhamento das fábricas algodoeiras e de expansão da produção de tecidos, e a evolução da Fábrica Votorantim, que se tornou a maior firma de tecidos de algodão do estado de São Paulo - conforme a Tabela 8 - representando a unidade sorocabana $8 \%$ do capital total do setor algodoeiro paulista, empregando $9 \%$ dos operários, possuindo $6,3 \%$ dos teares e $7,1 \%$ dos fusos.

\section{Tabela 8}

As maiores fábricas de tecidos de algodão no Estado de São Paulo segundo o volume do capital investido, 1925 - libras esterlinas constantes

\begin{tabular}{l|c|c|c|c|c}
\hline Nome da firma (Proprietário) & Local & $\begin{array}{c}\text { Capital, } \\
\text { reserva e } \\
\text { debêntures } \\
\text { (em libras) }\end{array}$ & Operários & Teares & Fusos \\
\hline $\begin{array}{l}\text { Sociedade Anônima Fábrica } \\
\text { Votorantim }\end{array}$ & Sorocaba & 318.037 & 3.400 & 1.300 & 47.340 \\
\hline $\begin{array}{l}\text { Companhia Nacional de } \\
\text { Estamparia }\end{array}$ & Sorocaba & 263.077 & 1.500 & 1.167 & 42.000 \\
\hline São Paulo Alpargatas & Capital & 260.885 & 800 & 120 & 5.600 \\
\hline Cotonifício Rodolpho Crespi & Capital & 194.545 & 3.000 & 1.120 & 46.000 \\
\hline Companhia Taubaté Industrial & Taubaté & 185.009 & 1.600 & 780 & 34.000 \\
\hline $\begin{array}{l}\text { Total do Setor Algodoeiro (64 } \\
\text { firmas) }\end{array}$ & - & 3.949 .922 & 38.073 & 20.560 & 663.254 \\
\hline
\end{tabular}

Fonte: Boletim (abr. 1926, p. 63-67).

(45) O quociente de cobertura total é dado pela razão do ativo total dividido pelo passivo circulante. A liquidez corrente é dada pela razão do ativo circulante dividido pelo passivo circulante.

(46) O quociente de rentabilidade do ativo é dado pela razão da conta lucros e perdas somadas aos lucros suspensos e divididos pelo patrimônio líquido. 
Porém, os anos de prosperidade do setor têxtil, como Stein (1979, p. 123) descreve o período que vai do início do século até 1925, dariam lugar a uma conjuntura marcada pela crise do principal setor industrial brasileiro. Em que pese à forte importação de maquinário têxtil pelas fábricas nacionais entre 1921-1927, a produção nacional de tecidos de algodão em 1928 foi menor do que em 1920, queda semelhante ao que ocorreu com a produção no estado de São Paulo. Como demonstra Haber (1992, p. 344-348), a crise afligia os dois principais parques têxteis do Brasil, pois as principais firmas do setor no estado de Rio de Janeiro apresentavam números declinantes após 1925, no que concerne aos dividendos pagos e às taxas de retorno sobre o capital investido (Stein, 1979, p. 192; Cano, 1981, p. 292; Suzigan, 2000, p. 159).

As causas que fizeram da segunda metade da década de 1920 um lustro difícil ao setor têxtil algodoeiro podem ser elencadas: valorização cambial após 1924, sobretudo com aumento das receitas de exportação do café, perda de efetividade das alíquotas aduaneiras, que eram específicas e haviam sido fixadas em 1900, aumento na concorrência nacional devido à elevação do número de fábricas têxteis, que eram 241 no ano de 1921 e passaram a 359 em 1929, as necessidades de escalas mínimas de produção aos novos teares e fusos que foram importados no decênio. Estes fatores interligados dificultavam a obtenção de receitas às têxteis nacionais, enquanto que, de outra parte, a importação de tecidos de algodão mais do que dobrou entre 1923 e 1928 (Stein, 1979, p. 193; Suzigan, 2000, p. 160; Fishlow, 1972, p. 24; Cano, 1981, p. 180; Versiani; Versiani, 1977, p. 140; Vilella, 2000, p. 39).

O acirramento da concorrência levou algumas empresas a buscarem expedientes que revertessem a tendência de queda nas receitas como: a retenção de dividendos, a tentativa de eliminar atacadistas através da montagem de sistemas de vendas diretas, utilização do fundo de depreciação para custear as operações correntes; diminuição na jornada de trabalho e, no caso das grandes firmas, como a carioca América Fabril - naquele momento a maior empresa têxtil algodoeira do Brasil - o levantamento de empréstimos no exterior (Levy, 1994, p. 222; Stein, 1979, p. 136).

Entretanto, tais medidas eram paliativas e não alteravam o quadro de subutilização da capacidade instalada nas firmas têxteis que se via no estado de São Paulo e que se expressava também na Votorantim: no ano de 1916, a fábrica sorocabana possuía 1.109 teares, 36.000 fusos e 1.400 operários, já em 1925, a capacidade instalada era de 1.300 teares, 47.340 fusos e empregava 3.400 operários, números que se mantiveram em 1928. Mas, mesmo com o aumento no maquinário e no número de trabalhadores, a produção de tecidos da Votorantim em 1925 foi menor do que no ano de 1922 e, ademais, esta produção em 1929 foi igual ao nível alcançado no início da década ${ }^{47}$.

(47) Deic/Saic/SP (1930, p. 81); São Paulo (30 jun. 1922, p. 1922; 15 fev. 1923, p. 1923; 14 fev. 1925, p. 1233; 12 fev. 1926, p. 1243; 22 mar. 1931 p. 2327). Os dados disponíveis da produção de tecidos da Fábrica Votorantim indicam os seguintes resultados: em 1920, a Votorantim produziu 16 milhões de metros de tecidos; em 1922, a produção foi de 21 milhões de metros; em 1925, foi de 20 milhões e; em 1929, foi de 16 milhões de metros. 
A formação do Grupo Votorantim: as origens de um grupo econômico brasileiro no setor têxtil ...

Tabela 9

Balanços Patrimoniais da S. A. Fábrica Votorantim, 1925-1929 - em libras esterlinas constantes

\begin{tabular}{|c|c|c|c|}
\hline Anos & 1925 & 1927 & 1929 \\
\hline Ativo Circulante & 878.157 & 723.954 & 799.868 \\
\hline Caixa & 1.435 & 4.633 & 1.229 \\
\hline Venda de terrenos & 60.212 & 59.236 & 67.432 \\
\hline Devedores diversos & 318.567 & 180.687 & 313.659 \\
\hline Clientes (Letras a receber) & 185.426 & 185.911 & 190.914 \\
\hline Caução dos diretores & 1.766 & 945 & 984 \\
\hline Estoque de mercadorias e matérias-primas & 310.751 & 292.542 & 225.650 \\
\hline Ativo Permanente & 787.056 & 1.284 .951 & 1.027 .903 \\
\hline $\begin{array}{l}\text { Edifício da Fábrica, terrenos e vila operária, fábrica de } \\
\text { cimento Rodovalho, }\end{array}$ & 754.466 & 837.157 & 597.178 \\
\hline Terrenos diversos e propriedades agrícolas & 23.029 & 34.488 & 39.088 \\
\hline Debêntures em carteira & 5.189 & & \\
\hline Ações & 1.634 & 46.023 & 23.797 \\
\hline Acionistas & & 319.110 & 331.875 \\
\hline Móveis e utensílios & & 2.009 & \\
\hline Despesas e prêmio de reembolso do empréstimo externo & & 39.971 & 35.965 \\
\hline Contas a liquidar & 2.738 & 6.193 & \\
\hline Ativo Total & 1.665 .212 & 2.008 .905 & 1.827 .771 \\
\hline Passivo Circulante & 1.038 .541 & 1.108 .823 & 1.236 .638 \\
\hline Empréstimo externo & & 355.181 & 366.808 \\
\hline Emissão de debêntures & 31.684 & 33.920 & 35.277 \\
\hline Diversos credores & 446.674 & 273.466 & 575.545 \\
\hline Letras a Pagar & 327.178 & 244.486 & 23.846 \\
\hline Títulos descontados e caucionados & 184.476 & 153.858 & 171.247 \\
\hline Seção de terrenos & 31.662 & 26.545 & 52.633 \\
\hline Serviços médicos & 574 & & 146 \\
\hline Porcentagem dos diretores & 4.879 & 590 & 221 \\
\hline Salários a pagar & 9.582 & 11.724 & 6.490 \\
\hline Depósito dos diretores & 1.766 & 945 & 983 \\
\hline Debêntures sorteadas e juros não reclamados & 66 & & \\
\hline Impostos & & 4.916 & \\
\hline $\begin{array}{l}\text { Diferença de tipo sobre o resgate antecipado de } \\
\text { debêntures }\end{array}$ & & 3.192 & 3.442 \\
\hline
\end{tabular}

Continua... 
Tabela 9 - Continuação

\begin{tabular}{l|c|c|c}
\hline Anos & 1925 & 1927 & 1929 \\
\hline Patrimônio Líquido & 625.519 & 900.104 & 591.082 \\
\hline Capital & 110.399 & 472.756 & 491.667 \\
\hline Reservas & 260.453 & 419.855 & 96.539 \\
\hline Fundo de depreciação & 91.410 & & \\
\hline Lucros suspensos & 119.186 & & \\
\hline Lucros e perdas & 44.071 & 7.493 & 2.876 \\
\hline Passivo Total & 1.664 .060 & 2.008 .927 & 1.827 .720 \\
\hline Indicadores financeiros & & & \\
\hline Quociente Cobertura Total & & & \\
\hline Liquidez Corrente & 1,603 & 1,811 & 1,478 \\
\hline Quociente Rentabilidade Patrimônio Líquido & 0,845 & 0,652 & 0,646 \\
\hline Quociente Rentabilidade do Ativo & 0,261 & 0,008 & 0,005 \\
\hline \% Capital de Terceiros no Ativo Total & 0,098 & 0,004 & 0,002 \\
\hline \% Capital Próprio no Ativo Total & 62,4 & 55,2 & 67,7 \\
\hline Imobilização do Capital & 37,6 & 44,8 & 32,3 \\
\hline Font: São Paulo, 12/02/1926, & 1,258 & 1,427 & 1,739 \\
\hline
\end{tabular}

Fonte: São Paulo, 12/02/1926, p. 1243; 16/02/1928; p. 1953; 23/02/1930, p. 1995.

Conforme a Tabela 9, os resultados patrimoniais do Grupo Votorantim (fábrica têxtil, fábrica de cimento, fábrica de cal, ferrovia e seção de terrenos) entre 1925-1929, no que tange aos aspectos financeiros, demonstraram pouca variação quando comparados à primeira metade da década de 1920 (tabela 7): o quociente de cobertura total médio foi de 1,631 e a liquidez corrente ficou em 0,714, indicando uma boa capacidade de solvência do Grupo no curto e, sobretudo, no longo prazo. Ademais, observava-se novamente uma das especificidades da Votorantim que era o elevado montante do ativo que se encontrava imobilizado na rubrica imobilização do capital, que chegou a $147 \%$ do patrimônio líquido, corroborado pelas grandes plantas industriais e demais ativos - como os terrenos na cidade de São Paulo e Paraná - que poderiam servir de garantias na tomada de empréstimos institucionais.

Todavia, quando avaliados os indicadores de rentabilidade, nota-se a congruência entre a crise no setor têxtil algodoeiro na segunda metade dos anos 1920, apontada pela historiografia econômica, e a situação patrimonial da Votorantim. Se, entre 1922-1924, a rentabilidade do patrimônio líquido do Grupo sorocabano teve média de $42 \%$ e a rentabilidade do ativo alcançou $17 \%$, por sua vez, os mesmos indicadores para o período 1925-1929 foram, respectivamente, de 9,1\% e 10,4\%. Ademais, a tabela 9 demonstra que, assim como a América Fabril, o Grupo Votorantim buscou no exterior o auxílio financeiro para atravessar a crise, pois em 1926, levantou um empréstimo em Londres com prazo de quitação de 20 anos e que 
A formação do Grupo Votorantim: as origens de um grupo econômico brasileiro no setor têxtil ...

se tornou a maior conta do passivo da Votorantim entre 1927-1929, sendo responsável por manter os capitais de terceiros como principal fonte de financiamentos do Grupo, com média $62 \%$ do capital no ativo total - entre 19221924, a cifra foi $61 \%$, mas com predomínio das emissões de debêntures.

Tabela 10

Demonstração de Lucros e Perdas do Grupo Votorantim, 1921-1927 - em libras esterlinas constantes

\begin{tabular}{|c|c|c|c|c|c|}
\hline & 1921 & 1922 & 1924 & 1925 & 1927 \\
\hline \multicolumn{6}{|l|}{ Receitas } \\
\hline Votorantim (fábrica têxtil) & 129.719 & 78.259 & 173.750 & 152.350 & 96.891 \\
\hline Itupararanga (cal) & 10.646 & 5.871 & 8.525 & 10.068 & 6.004 \\
\hline Rodovalho (cimento) & 2.017 & 1.138 & 943 & 821 & 1.135 \\
\hline Diversos & 10.184 & 12.155 & 19.242 & 4.195 & 0 \\
\hline Estrada de Ferro Elétrica & & & 1.455 & 2.517 & 19.501 \\
\hline Seção de Terrenos & & & & 16.891 & 18.887 \\
\hline Renda de imóveis & 997 & 776 & 1.045 & 375 & \\
\hline Receita Total & 153.563 & 98.199 & 204.960 & 187.217 & 142.465 \\
\hline \multicolumn{6}{|l|}{ Despesas } \\
\hline Despesas Gerais & 7.146 & 5.457 & 12.049 & 14.948 & 17.657 \\
\hline Juros e descontos & 17.087 & 9.440 & 16.844 & 59.527 & 42.430 \\
\hline Serviços do empréstimo externo & & & & & 32.880 \\
\hline Diferenças de algodão & & & & 31.684 & \\
\hline Seguros & 3.500 & 1.862 & 5.225 & 4.416 & 6.902 \\
\hline $\begin{array}{l}\text { Maquinismos diversos (depreciação } \\
\text { no estoque) }\end{array}$ & & & & & 2.860 \\
\hline $\begin{array}{l}\text { Prêmio de emissão do empréstimo } \\
\text { externo (depreciação de 20\%) }\end{array}$ & & & & & 1.962 \\
\hline Impostos & 753 & 750 & 6.557 & 2.760 & 4.538 \\
\hline Aluguéis & 778 & 517 & 369 & 397 & 1.655 \\
\hline $\begin{array}{l}\text { Despesas de empréstimo externo } \\
\text { (depreciação de } 10 \% \text { ) }\end{array}$ & & & & & 496 \\
\hline Despesas da agência no Rio & & & & & 1.040 \\
\hline Serviços médicos & & & & & 969 \\
\hline Vencimentos dos Diretores & 875 & 1.164 & 2.951 & 3.179 & 1.773 \\
\hline Depreciação (móveis e utensílios) & & & 184 & 44 & 142 \\
\hline Donativos & 1.361 & 853 & 1.557 & 1.236 & 1.513 \\
\hline Gratificações & & & 5.471 & 4.593 & 4.184 \\
\hline Diversas contas & & & & & 11.275 \\
\hline Custeio & 31 & 26 & & & \\
\hline
\end{tabular}

Continua... 
Tabela 10 - Continuação

\begin{tabular}{l|c|c|c|c|c}
\hline & 1921 & 1922 & 1924 & 1925 & 1927 \\
\hline Eventuais & 4.035 & & & 3.179 & \\
\hline Juros e despesas de debêntures & 1.458 & 724 & 41 & 22 & \\
\hline Despesa Total & 37.024 & 20.793 & 51.248 & 125.985 & 132.276 \\
\hline Conta de Distribuição & & & & & \\
\hline Fundo de depreciação & 11.642 & 7.733 & 15.348 & 6.116 & 1.016 \\
\hline Reserva especial & 11.642 & 7.733 & 15.348 & 6.116 & 1.016 \\
\hline Porcentagem dos Diretores & 9.309 & 6.181 & 12.275 & 4.880 & 615 \\
\hline Gratificações & 2.309 & & & & \\
\hline Saldo para dividendos & 81.545 & 55.707 & 110.615 & 44.071 & 7.517 \\
\hline Resultado do Exercício & 116.539 & 77.406 & 153.712 & 61.232 & 10.189 \\
\hline
\end{tabular}

Fonte: São Paulo (30 jun. 1922, p. 1922; 15 fev. 1923, p. 1923; 14 fev. 1925, p. 1233; 12 fev. 1926, p. $1243 ; 15$ fev. 1928 , p. 1471).

Conforme a Tabela 10, vemos através da demonstração de lucros e perdas do Grupo Votorantim na década de 1920 que a fábrica têxtil respondia por $80 \%$ das receitas do Grupo entre 1921-1927. Sendo assim, a crise têxtil se evidenciou na Votorantim através de uma queda na rentabilidade de sua principal atividade, cuja geração de receitas declinou 56\% entre 1924 e 1927, ao passo que, as despesas se expandiram em $158 \%$ no mesmo período. Estes dados explicam o comportamento do resultado do exercício do Grupo que, pese a não ter apresentado prejuízo, viu seus lucros declinarem de 153 mil libras em 1924, para pouco mais de 10 mil libras em 1927, numa conjuntura marcada pelo aumento prévio da capacidade produtiva que não se realizava, posto que o mercado encontrava-se saturado pelo aumento da importação de tecidos, bem como pela ampliação dos concorrentes nacionais.

O ano de 1925 marca o início da crise na Votorantim, quando as despesas passaram de 51 mil libras no ano anterior, para a cifra de 125 mil libras devido, principalmente, aos maiores valores gastos com juros e descontos, indicando um custo maior com a rolagem de dívidas e tomada de crédito. Esta situação se agravou em 1926, ano em que a Votorantim obteve um empréstimo em Londres, cujo serviço do empréstimo, somado à conta juros e descontos, foram responsáveis por mais de $57 \%$ das despesas naquele ano.

De um lado, o fato do Grupo Votorantim ter conseguido atravessar esta conjuntura tormentosa em sua principal atividade pode ser imputado às medidas que Stein (1979) apontou terem sido adotadas por outras firmas do setor, como a não distribuição de dividendos que, no caso da Votorantim, era um expediente que a diretoria do Grupo adotara no ano de 1921 e seria mantido de forma ininterrupta até 1931 - os dividendos eram levados à conta lucros suspensos e se tornavam reservas 
- ou seja, a Votorantim antecipou-se a um cenário de crise buscando capitalizar-se através de seus lucros ${ }^{48}$.

A essa estratégia da diretoria somou-se o fato da Votorantim ser constituída como um grupo econômico, ou seja, a reunião de diversos empreendimentos que, a princípio, foram engendrados para viabilizar a produção têxtil, mas que possibilitavam, ao mesmo tempo, a obtenção de novas receitas, transformando-se em uma vantagem competitiva frente a empresas concentradas unicamente na atividade têxtil, cujos lucros estavam em declínio na segunda metade dos anos 1920 (Colpan; Hikino, 2010, p. 41; Leff, 1974, p. 96). Como aponta Valdaliso (2002, p. 588), as estratégias de crescimento dos grupos econômicos - em países como Brasil, México, Argentina e nações asiáticas - conjugava os seguintes fatores: integração vertical, diversificação, elevado poder de mercado nas atividades nucleares do grupo e acesso facilitado às fontes de crédito. Dessa forma, o grupo econômico aproveita-se de seus recursos e capacidades excedentes dotadas pelos empreendimentos paralelos para aumentar seu poder de mercado, gerar barreiras aos concorrentes e, também, superar eventuais crises nas atividades centrais.

Neste sentido, a Tabela 10 demonstra que em 1924 a fábrica têxtil foi responsável por $85 \%$ das receitas, mas, em 1927, esta participação foi reduzida a $68 \%$, enquanto, neste último ano, a fábrica de cal (Itupararanga) contribuiu com 4,2\% das receitas, a fábrica de cimento (Rodovalho) com $0,8 \%$ e, sobretudo, houve elevação nas receitas da Estrada de Ferro Votorantim e na Seção de Terrenos, que contribuíram com $13,7 \%$ e $13,2 \%$ do montante no referido ano.

O relatório da diretoria da S. A. Fábrica Votorantim para o ano de 1925 descreve a importância dos empreendimentos componentes do Grupo para a formação das receitas naquele ano. Em relação à Estrada de Elétrica Votorantim, o alargamento de bitola iniciado em 1922, que passou para 1 metro, foi finalizado em 1925, permitindo um fluxo direto dos vagões que vinham da Estrada de Ferro Sorocabana, facilitando o transporte de cargas e passageiros e, consequentemente, ampliando as receitas (São Paulo, 12 fev. 1926, p. 1242).

Na Seção de Terrenos, a Votorantim, detentora de vastas terras na região da capital paulista e no Paraná, promovia um vultoso empreendimento imobiliário na cidade de São Paulo, através da venda de seus terrenos no loteamento Brooklyn Paulista (atualmente Brooklyn Velho), iniciado em 1922, além da venda de terrenos em São Caetano do Sul, terras que tiveram seu valor de venda duplicado entre 1924 e 1925, devido à grande procura. Neste empreendimento, a Votorantim vendia os

(48) São Paulo (12 fev. 1926, p. 1242; 15 fev. 1928, p. 1471; 16 fev. 1928, p. 1953). O Relatório da Diretoria da S. A. Fábrica Votorantim para o ano de 1925 diz: "Não julgando ainda a Diretoria oportuna a ocasião para distribuir dividendos por assim a exigirem os interesses sociais, pede a vossa aprovação a proposta de serem levados a conta de lucros suspensos os proventos auferidos a constantes do balanço ora analisado". 
terrenos a prestações sem juros e, ademais, por produzir materiais de construção cal, cimento e tijolos em Itupararanga e Rodovalho - podia fornecê-los a preços menores, o que, segundo a publicação, era motivo da grande procura pelos terrenos (São Paulo, 12/02/1926, p. 1242).

Calcada nos empreendimentos que compunham o grupo, pôde a Votorantim suportar a queda nas receitas da atividade têxtil na segunda metade da década de 1920, conjuntura que seria modificada a partir de 1929, quando os apelos dos grandes industriais do setor levaram o Governo Federal a efetuar uma revisão das tarifas alfandegárias dos tecidos de algodão em janeiro de 1929, redundando na queda da importação de têxteis naquele ano e no seguinte, resultado que também deve ser creditado em grande parte ao encarecimento dos gêneros estrangeiros pelo Crash da Bolsa de Nova Iorque e a Depressão dos anos 1930 (Stein, 1979, p. 135-136). Em 1929, o Grupo Votorantim possuía a maior empresa têxtil algodoeira do estado de São Paulo, tendo a Fábrica Votorantim, localizada em Sorocaba, o capital (que incluía reservas e debêntures) de 858.474 libras esterlinas e uma capacidade instalada de 1.390 teares, 70.020 fusos e contando com 2.455 operários que produziam tecidos tintos, brancos, crus e estampados ${ }^{49}$.

\section{Considerações finais}

O trabalho buscou elucidar a formação do Grupo Votorantim, de suas origens na última década do século XIX até a sua consolidação como a principal firma têxtil algodoeira paulista na década de 1920. Esta trajetória iniciou-se na cidade de Sorocaba, no ano de 1891, quando o banco União de São Paulo - o maior banco paulista à época - adquiriu terras para formar a Fábrica Têxtil Votorantim. Para viabilizar a produção, o banco também construiu nas adjacências uma pequena central hidrelétrica e uma ferrovia, a Estrada de Ferro Votorantim.

O Banco União, tendo restringido suas atividades à administração dos ativos industriais em 1906, constava como proprietário da Fábrica Votorantim, uma das maiores firmas têxteis algodoeiras de São Paulo na primeira década do século XX. Ao passo que se dava a expansão da Votorantim no setor têxtil, seu controlador enfrentava agruras financeiras que o levaram a arrendar a empresa para o empresário português Antonio Pereira Ignácio em 1914. Com a falência do União de São Paulo em janeiro de 1918, Pereira Ignácio, junto de Nicolau Scarpa e demais acionistas minoritários, arremataram o espólio do banco em que se destacava a Fábrica

(49) Segundo a Estatística Industrial do estado de São Paulo no ano de 1929, as maiores firmas têxteis algodoeiras, segundo o volume do capital investido, eram as seguintes: Fábrica Sant'Anna (São Paulo, 639. 166 libras esterlinas, 703 operários, 525 teares e 10.000 fusos), Companhia Nacional de Estamparia (Sorocaba, 619.869 libras, 1.200 operários, 1.100 teares e 42.000 fusos) e Cotonifício Scarpa (São Paulo, 608.265 libras, 1.040 teares, 35.848 fusos e nenhum operário, pois suas atividades estavam paralisadas em virtude de dificuldades econômicas (Deic/Saic/SP, 1929, p. 77-81). 
Votorantim, composta da unidade têxtil, exploração de cal, ferrovia e terrenos em São Paulo e no Paraná.

Em 1919, Pereira Ignácio adquiriu o controle acionário dos diversos empreendimentos que compunham a Fábrica Votorantim e a eles agregou suas unidades descaroçadoras de algodão e a Fábrica de Cimento Rodovalho, formando então o Grupo Votorantim, que atuava no setor têxtil (Fábrica Votorantim em Sorocaba - SP), exploração de cal (Caieiras de Itupararanga em Sorocaba - SP), produção de cimento (Fábrica Rodovalho em São Roque - SP), além de administrar a Estrada de Ferro Votorantim.

Estes diversos empreendimentos passaram por um processo de modernização de suas instalações e materiais - novas máquinas, aprimoramentos técnicos - que contou com duas fontes de financiamento: capitais de terceiros (empréstimos hipotecários) e capitais próprios (reinvestimentos dos lucros através da não distribuição de dividendos). Com esses investimentos, a Fábrica Votorantim, responsável pela maior parte das receitas do Grupo, tornou-se a principal firma têxtil algodoeira de São Paulo em 1925.

Na segunda metade dos anos 1920, o setor têxtil nacional passou a sofrer com a forte concorrência dos tecidos importados, cujos níveis de importação se ampliaram a partir de 1925, deflagrando queda nas receitas de diversas empresas do setor. Para debelar os efeitos desta conjuntura adversa que, no caso da Votorantim, expressaram-se na forma de uma queda na rentabilidade, nas receitas, aumento das despesas e, consequentemente, menores lucros, o Grupo sorocabano buscou um grande empréstimo em Londres e, sobretudo, valeu-se das receitas geradas pelos empreendimentos componentes da Votorantim, como a Estrade Ferro Votorantim e a Seção de Terrenos. A ampliação das receitas nestes empreendimentos possibilitou uma menor queda nas receitas do Grupo e sua consolidação como maior firma têxtil algodoeira do estado de São Paulo e um dos principais grupos econômicos do Brasil no início dos anos 1930.

\section{Referências bibliográficas}

\section{Fontes primárias}

ATA. Ata da Assembleia Geral Extraordinária da Sociedade Anônima Fábrica Votorantim de 07 de outubro de 1922. São Paulo: Centro de Memória Votorantim.

BALANÇOS. Balanços da Fábrica Têxtil Votorantim, 1894-1896. In: LIVRO Diário da Fábrica Votorantim (SAFV) para os anos de 1894-1896. São Paulo: Grande Typographia a Vapor, Centro de Memória do Grupo Votorantim.

BOLETIM. Boletim da Diretoria de Indústria e Comércio do Estado de São Paulo. Deic/Sacop/SP: São Paulo, 1912 a 1926. 
DEIC/SAIC/SP. Estatística Industrial do Estado de São Paulo, 1928-1930.

EFEV. Breve histórico da Estrada de Ferro Elétrica Votorantim (EFEV). São Paulo: Centro de Memoria Grupo Votorantim.

ESCRITURA. Escritura de constituição da Sociedade Anônima Fábrica Votorantim de 15 de janeiro de 1918. São Paulo: Ofício do $8^{\circ}$ Tabelião de Notas da Comarca da cidade de São Paulo, Centro de Memória Votorantim.

SAFV. Livro Diário da Sociedade Anônima Fábrica Votorantim (SAFV) para o ano de 1918-1919. São Paulo: Centro de Memória do Grupo Votorantim.

SAFV. Balanço da Sociedade Anônima Fábrica Votorantim para o ano de 1923. São Paulo: Centro de Memória do Grupo Votorantim.

SÃO PAULO. Diário Oficial do Estado de São Paulo, 1918-1932. Consulta aos balanços contábeis, demonstrações de lucros e perdas, e aos relatórios de diretoria da Sociedade Anônima Fábrica Votorantim e informações sobre o Banco União de São Paulo.

\section{Fontes secundárias}

ABREU, M. P. (Org.). A ordem do progresso: cem anos de política econômica republicana, 1889-1989. Rio de Janeiro: Campus, 1989.

ALBUQUERQUE, R. H. P. L. Capital comercial, indústria têxtil e produção agrícola: as relações de produção na cotonicultura paulista, 1920-1950. São Paulo: Hucitec, 1982.

ALDRIGHI, D. M.; POSTALI, F. A. S. Business groups in Brazil. In: COLPAN, A. M.; HIKINO, T.; LINCOLN, J. R. The Oxford Handbook of business groups. Oxford: Oxford University Press, 2010.

AURELIANO, L. No limiar da industrialização. Campinas, SP: Unicamp/IE, 1999. BERTOLA, L.; OCAMPO, J. The economic development of Latin America since the Independence. Oxford: Oxford University Press, 2012.

BAER, W. A. Industrialização e o desenvolvimento econômico no Brasil. Rio de Janeiro: Fundação Getúlio Vargas, 1975.

BIONDI, L. A greve geral de 1917 em São Paulo e a imigração italiana: novas perspectivas. Cad. AEL, v. 15, n. 27, 2009.

BONELLI, R. As estratégias dos grandes grupos industriais brasileiros nos anos 90. Brasília: Ipea, jul. 1998. (Texto para Discussão, n. 569).

BRASIL. Ministerio do Trabalho, Indústria e Comércio. Indústria têxtil algodoeira. São Paulo: Cruzeiro, 1946. 
CANO, W. Raízes da concentração industrial em São Paulo. T. A. Queiroz, 1981. CARONE, E. A evolução industrial de São Paulo (1889-1930). São Paulo: Editora Senac, 2001.

CHANDLER, A. D. Alfred Chandler: ensaios para uma teoria histórica da grande empresa. Thomas K. Mc Craw (Org.). Rio de Janeiro: Fundação Getúlio Vargas, 1998.

CALDEIRA, J. Votorantim 90 anos: uma história de trabalho e superação. São Paulo, SP: Mameluco, 2007.

COLPAN, A. M.; HIKINO, T. Foundations of business groups: towards an integrated framework. In: COLPAN, A. M.; HIKINO, T.; LINCOLN, J. R. The Oxford Handbook of business groups. Oxford: Oxford University Press, 2010.

DEAN, W. A Industrialização de São Paulo. São Paulo: Difel, 1971.

DELFIM NETTO, A. O problema do café no Brasil. Rio de Janeiro: Campinas, SP: Facamp/ Editora da UNESP, 2009.

DESSOTTI, I. C. C. Trajetória da luta operária em Sorocaba: a greve de 1917. Histórica (Revista Eletrônica do Apesp), 2006.

FAUSTO, B. Expansão do café política cafeeira. In: FAUSTO, B. História Geral da Civilização Brasileira. Tomo III (4v.). O Brasil Republicano, $1^{\circ}$ volume: Estrutura de Poder e Economia (1889-1930). Rio de Janeiro: Bertrand Brasil, 2006.

FERREIRA, M. M.; GOMES, A. C. Industrialização e classe trabalhadora no Rio de Janeiro: novas perspectivas de análise. Rio de Janeiro: CPDOC, 1988.

FRANCO, G. H. B.; LAGO, L. A. C. O processo econômico. In: SCHWARCZ, L. M. A abertura para o mundo: 1889-1930. Rio de Janeiro: Objetiva, 2012.

GONÇALVES, R. Grupos econômicos: uma análise conceitual e teórica. Revista Brasileira de Economia, Rio de Janeiro, v. 45, n. 4, p. 491-518, out./dez. 1991.

GONÇALVES, R. Capital financeiro, bancário e industrial no Brasil. Economia e Sociedade, Campinas, SP, n. 13, p. 179-189, dez. 1999.

GRANOVETTER, M. Business groups and social organization. In: SMELSER, N. J.; SWEDBERG, R. The handbook of economic sociology. Oxfordshire: Princeton University Press, Princeton, 2005.

HABER, S. Industrial concentration and the capital markets: a comparative study of Brazil, Mexico, and the United States, 1830-1930. The Journal of Economic History, v. 51, n. 3, p. 559-580, 1991. 
HABER, S. Business enterprise and the great depression in Brazil: a study of profits and losses in textile manufacturing. Business History Review, n. 66, p. 335-363, Summer 1992.

HANLEY, A. G. Native capital: financial institutions and economic development in Sao Paulo, Brazil, 1850-1920. Stanford, Calif.: Stanford University, 2005.

HOBSON, J. A. A evolução do capitalismo moderno. São Paulo: Abril Cultural, 1983.

IPEADATA. Taxa de câmbio média mensal da libra esterlina (réis por pence) na praça do Rio de Janeiro (RJ). Recuperado de: http://www.ipeadata.gov.br.

KHANNA, T.; YAFEH, Y. Business groups in emerging markets: paragons or parasites? Journal of Economic Literature, v. XLV, p. 331-372, jun. 2007.

KING, R. B. La industria textil fabril em México, 1900-1910. In: BOLIO, M. T. e

VALDEZ, J. M. C. Formación empresarial, fomento industrial y compañías agrícolas en el México del siglo XIX. México: Ciesas, 2003.

LAMARÃO, S. T. N. A energia elétrica e o parque industrial carioca (1808-1920). Simpósio internacional Globalización, innovación y onstrucción de redes técnicas urbanas em América y Europa, 1890-1930. Universidade de Barcelona, Faculdade de Geografia e História, 23-26 de janeiro de 2012.

LEFF, N. H. El espíritu de empresa y la organización industrial en los países menos desarrolalados: los grupos. El Trimestre Económico, v. XLI, n. 3, jul./sept. 1974.

LEVY, Maria Bárbara. A indústria do Rio de Janeiro através de suas sociedades anônimas. Rio de Janeiro: Editora UFRJ; Secretaria Municipal de Cultura do Rio de Janeiro, 1994.

LLOYD, R. et. al. Impressões do Brazil no século vinte. London: Lloyd's Greater Britain Publishing Company, 1913.

LOUREIRO, F. P. Nos fios de uma trama esquecida: a indústria têxtil paulista nas décadas pós-Depressão (1929-1950). São Paulo, 2007. Dissertação (Mestrado) Faculdade de Filosofia, Letras e Ciências Humanas, Universidade de São Paulo.

MARCONDES, R. L.; HANLEY, A. G. Bancos na transição republicana em São Paulo: o financiamento hipotecário (1888-1901). Estud. Econ., São Paulo, v. 40, n. 1, mar. 2010.

MARCONDES, R. L. Crédito privado antes da grande depressão do século XX: o mercado hipotecário. Estud. Econ. [online], v. 44, n. 4, p. 749-786, 2014.

MARCOVITCH, J. Pioneiros \& Empreendedores: a saga do desenvolvimento no Brasil. São Paulo: Edusp, 2009. v. 2. 
MELLO, J. M. C. O capitalismo tardio. Contribuição à revisão crítica da formação e do desenvolvimento da economia brasileira. Campinas: Unicamp/IE, 2009.

MELO, H. P. de. O café e a economia fluminense: 1889/1920. SILVA, Sérgio; SZMERECSÁNY, Támas (Org). História econômica da Primeira República. São Paulo: Hucitec, 2002.

MITCHELL, B. R. International historical statistics: Europe, 1750-2005. $6^{\text {th }}$ ed. Houndmills, Basingstoke, Hampshire; New York, NY: Palgrave Macmillan, 2007.

NEGRI, B. Concentração e desconcentração industrial em São Paulo (1880-1990). Campinas: Unicamp, 1996.

PASTORE, J. Antonio Ermírio de Moraes: memórias de um diário confidencial. São Paulo: Planeta, 2013.

PENROSE, E. A teoria do crescimento da firma. Campinas, SP, Edunicamp, 2006.

RIBEIRO, M. A. R. Condições de trabalho na indústria têxtil paulista (18701930). São Paulo, SP: Hucitec: Editora da Unicamp, 1988.

ROCK, D. A Argentina de 1914 a 1930. In: BETHELL, L. História da América Latina: de 1870 a 1930. São Paulo: Edusp, 2008. v. V.

SAES, F. A. M. Crédito e bancos no desenvolvimento da economia paulista, 1850 1930. São Paulo: IPE/USP, 1986.

SANTOS, L. B. Reestruturação, internacionalização e novos territórios de acumulação do Grupo Votorantim. Dissertação (Mestrado)- FCT/Unesp, Presidente Prudente, SP, 2008.

SCANTIMBURGO, J. José Ermírio de Moraes: o homem, a obra. São Paulo: Companhia Editora Nacional, 1975.

SILVA, S. Expansão cafeeira e origens da indústria no Brasil. São Paulo: AlfaÔmega, 1995.

SILVA, G. P. Uma dinastia do capital nacional: a formação da riqueza dos Lacerda Franco e a diversificação na economia cafeeira paulista (1803-1897). Tese (Doutorado), Universidade Estadual de Campinas, Instituto de Economia, Campinas, SP, 2011.

STEIN, S. J. Origens e evolução da indústria têxtil no Brasil, 1850-1950. Rio de Janeiro: Campus, 1979.

SUZIGAN, W. Indústria brasileira: origem e desenvolvimento. São Paulo: Ed. Hucitec/ Ed. Unicamp, 2000.

TANNURI, L. A. O encilhamento. São Paulo: Hucitec, 1981. 
VALDALISO, J. M. Grupos empresariales, marco institucional y desarrollo económico en España en el siglo XX: los negócios de la Família Aznar (c. 1937-c. 1983). Revista de Historia Económica, v. 20, n. 3, p. 577-624, 2002.

VERSIANI, F. R.; VERSIANI, M. T. A industrialização brasileira antes de 1930: uma contribuição. In: VERSIANI, F. R.; BARROS, J. R. M. (Org.). Formação econômica do Brasil. São Paulo, 1977.

VERSIANI, F. R. Industrialização: a década de 20 e a depressão. Pesquisa e Planejamento Econômico, v. 14, abr. 1984.

VILlELA, A. V.; SUZIGAN, W. Política do governo e crescimento da economia brasileira, 1889-1945. Rio de Janeiro: Ipra/Inpes, 1973. 